\title{
'It's real, not fake like a park': Residents' perception and use of informal urban green-space in Brisbane, Australia and Sapporo, Japan
}

Authors' manuscript, accepted at Landscape and Urban Planning July 11, 2015.

Version of record: http://dx.doi.org/10.1016/j.landurbplan.2015.07.003

Christoph D. D. RUPPRECHT ${ }^{1,2}$ (Corresponding author)

Email: $\quad$ christoph.rupprecht@griffithuni.edu.au

Address: $\quad$ Room 3.16, Building G31, Griffith University QLD 4222, Australia

Phone: $\quad+6175552-9340$

Jason A. BYRNE ${ }^{1,2}$ (jason.byrne@ griffith.edu.au)

Hirofumi UEDA ${ }^{3}$ (h.ueda@scu.ac.jp)

Alex LO ${ }^{4}$ (alexloyh@hku.hk)

\section{Affiliations}

1. Environmental Futures Research Institute, Griffith University, Nathan QLD 4111, Australia

2. Griffith School of Environment, Griffith University, Gold Coast QLD 4222, Australia

3. School of Design, Sapporo City University, Sapporo 005-0864, Japan

4. The Kadoorie Institute, University of Hong Kong, Hong Kong

\begin{abstract}
:
Urban parks and gardens may be failing to meet the diverse "nature needs" of a growing global urban population. Informal urban greenspace (IGS) such as vacant lots, street or railway verges and riverbanks may provide space for unstructured recreation and nature contact. Yet we know little about residents' relationship with IGS outside of Europe and North America, what factors influence IGS use and evaluation, or what role geographic and cultural context play. Our paper combines qualitative and quantitative methods to examine how residents in Brisbane, Australia $(n=123)$ and Sapporo, Japan $(n=163)$ perceive, evaluate and use IGS. Using statistical methods (e.g. correlation analysis) we analyzed what factors influence how respondents interact with IGS, including the amount of formal greenspace within 500m of survey locations using a GIS buffer analysis. Results were tested for differences and similarities between the cities. We found that respondents knew of IGS in their neighborhood $(>80 \%)$, appreciated and used it $(>30 \%)$, but more respondents in Brisbane used and appreciated IGS. The influence of demographic factors and local formal
\end{abstract}


greenspace area was limited, but respondents' attitude towards urban nature was correlated with IGS evaluation. Littering was perceived as IGS' most common problem (90\% of respondents), but was reported by $<20 \%$ of IGS users. Geographic (e.g., IGS type prevalence) and cultural (e.g., human-nature relationship) contexts represented potential influence factors. We argue that the liminal nature of IGS (e.g., liability) management poses a challenge traditional greenspace planning. To address this problem, further research should explore participatory management approaches.

\section{Research highlights:}

- Over $80 \%$ of respondents knew of informal greenspace in their neighborhood

- $52 \%$ of respondents in Brisbane and $31 \%$ Sapporo used IGS for recreation

- Reasons for use: proximity, diverse flora/fauna, no use restrictions or crowding

- Influence of demographic factors on IGS use and evaluation was limited

- Cultural and geographic context may explain different IGS evaluation and use

Keywords: wildscape; city; landscape; recreation; GIS; mixed methods

\section{Introduction}

Do parks and gardens in cities meet the diverse 'nature needs' of growing global urban populations? An increasing body of recent research suggests the answer may be 'no.' Urban residents' greenspace needs include contact with nature, encountering beauty, relaxation, and recreation (Matsuoka \& Kaplan, 2008). Recent research suggests that 'formal greenspaces' (like parks) may not be sufficient to meet some residents' needs, especially in more dense environments (Byrne, Sipe, \& Searle, 2010; Ward Thompson, 2012). In such circumstances, city dwellers can be forced to travel long distances if they want to access regional open spaces to compensate for deficient local greenspace (Næss, 2005). Yet some residents will be unable to travel due to time, financial cost, or disability (Maat \& de Vries, 2006). Moreover, local governments may lack the finances and/or space necessary to develop new urban parks. Although researchers have shown that even small pocket parks can be valuable, some cities may lack even these spaces. And pocket parks cannot satisfy active recreation needs (Nordh \& Østby, 2013; Peschardt, Schipperijn, \& Stigsdotter, 2012). What options are available then to address the problem of greenspace deficiency? 
Scholars have recently begun looking towards what might be called informal urban greenspace (IGS), urban wildscape or 'terrain vague' - in other words 'ambiguous spaces of the city' (Barron \& Mariani, 2013). These spaces include vacant lots, brownfields, street or railway verges (i.e. nature strips), for potential solutions (Campo, 2013; Jonas, 2007; Jorgensen \& Keenan, 2012; Kremer, Hamstead, \& McPhearson, 2013; Rupprecht \& Byrne 2014a; Schneekloth, 2007). In a recent special issue on vacant urban land in the journal Cities, researchers have discussed the socio-cultural and ecological opportunities of the abandoned or left-over spaces, including the Petite Ceinture railway circuit in Paris (Foster, 2014), community gardens and vacant lands in the USA (Drake \& Lawson, 2014), and opportunities to use private property in North Denver for public purposes (Langegger, 2013).

In a recent systematic review (Rupprecht \& Byrne, 2014b), we discuss the character of IGS and note that the informal, often unintentional formation of these spaces, and their uncertain legal, socio-economic, and ecological status gives them a liminal quality. We have found that IGS nevertheless appears to play an important role for urban residents and is emerging as an important topic in urban greenspace research. Our review shows that residents can distinguish between IGS and formal greenspace, and cherish the unique features of IGS. Some residents use IGS as recreation spaces (Platt, 2012; Unt, Travlou, \& Bell, 2013), benefiting from the flexibility and freedom of restrictions conferred by the 'indeterminacy of loose space' (Franck \& Stevens, 2007). However, we also note that researchers have found that residents' relationship with IGS is complex and sometimes contradictory - negative cultural associations of 'vacancy' and/or decrepitude (Corbin, 2003) may mean that the full potential of IGS to meet urban residents' needs remains unrealized (Rink \& Herbst, 2011). Residents appear to prefer a medium level of human influence, because they dislike uniform and highly artificial spaces, but may also prefer a certain level of maintenance (Rupprecht \& Byrne, 2014b). However, IGS is relatively understudied and our understanding of the factors and processes underlying recreational use of IGS are not well understood.

A number of gaps exist in the recreational IGS literature (Rupprecht \& Byrne, 2014b). We know little about how residents outside of Europe and the US perceive and use IGS, or what specific factors influence their interactions with IGS. We also lack knowledge about how IGS use, perception, and influencing factors may differ between different geographical and cultural contexts. Quantitative studies that examine multiple IGS types are scarce. Better understanding such aspects of IGS use, perception, and factors influencing IGS interactions 
may improve our ability to 'tap into' the potential of IGS to satisfy the recreational needs of rapidly increasing urban populations globally. Such an understanding could assist planners by exploring alternative, cost-effective land management approaches to traditional park space provision (Campo, 2013), both in growing cities (where high land prices prohibit large public space acquisitions) and in shrinking cities with growing areas of vacant land (Haase, 2008). Finally, a better knowledge of residents' relationship with IGS may also have implications for environmental conservation outside of cities. The opportunities for local nature contact that these spaces offer could foster residents' interest in plants and animals and in turn engender support for protected areas (Dunn, Gavin, Sanchez, \& Solomon, 2006).

This paper reports the results of a study that asked the following three research questions. (1) How do urban residents perceive, evaluate and use IGS? (2) What factors might influence their IGS interactions? (3) How do IGS interactions and their influencing factors differ between cities in different cultural settings? To address these questions, we combined a quantitative-qualitative mixed methods questionnaire and a GIS analysis conducted in two locations, Brisbane, Australia and Sapporo, Japan (see Methods). We have found that over $80 \%$ of respondents knew of IGS in their neighborhood. $52 \%$ of respondents in Brisbane and $31 \%$ in Sapporo used IGS for recreation, with respondents choosing IGS over formal greenspace because it was closer, featured more diverse flora and fauna, and had no use restrictions. The influence of demographic factors on IGS use and evaluation is limited, but we identify cultural and geographic factors as potential drivers of difference in IGS evaluation and use between the two study locations.

To better understand the recreational potential of IGS as an alternative to formal greenspace, we need to look at the reasons why residents choose to use such greenspaces. The factors influencing such choices are best examined by visualizing their relationship in a conceptual model. We propose a model based on previous work by Byrne and Wolch (2009), which we have extended to account for different types of greenspace and factors previously overlooked (Figure 1). Specifically, our model includes ecological aspects in the context of greenspace as well as in the characteristics of greenspace itself, and adds private as well as informal greenspace as types of space potential users may choose to visit. Researchers have shown that ecological aspects (e.g., the presence of vegetation and/or wildlife) can play an important role in influencing how users perceive and appreciate greenspace (Gobster \& Westphal, 2004; Qiu, Lindberg, \& Nielsen, 2013; Nassauer, 1993; Özgüner \& Kendle, 2006). 


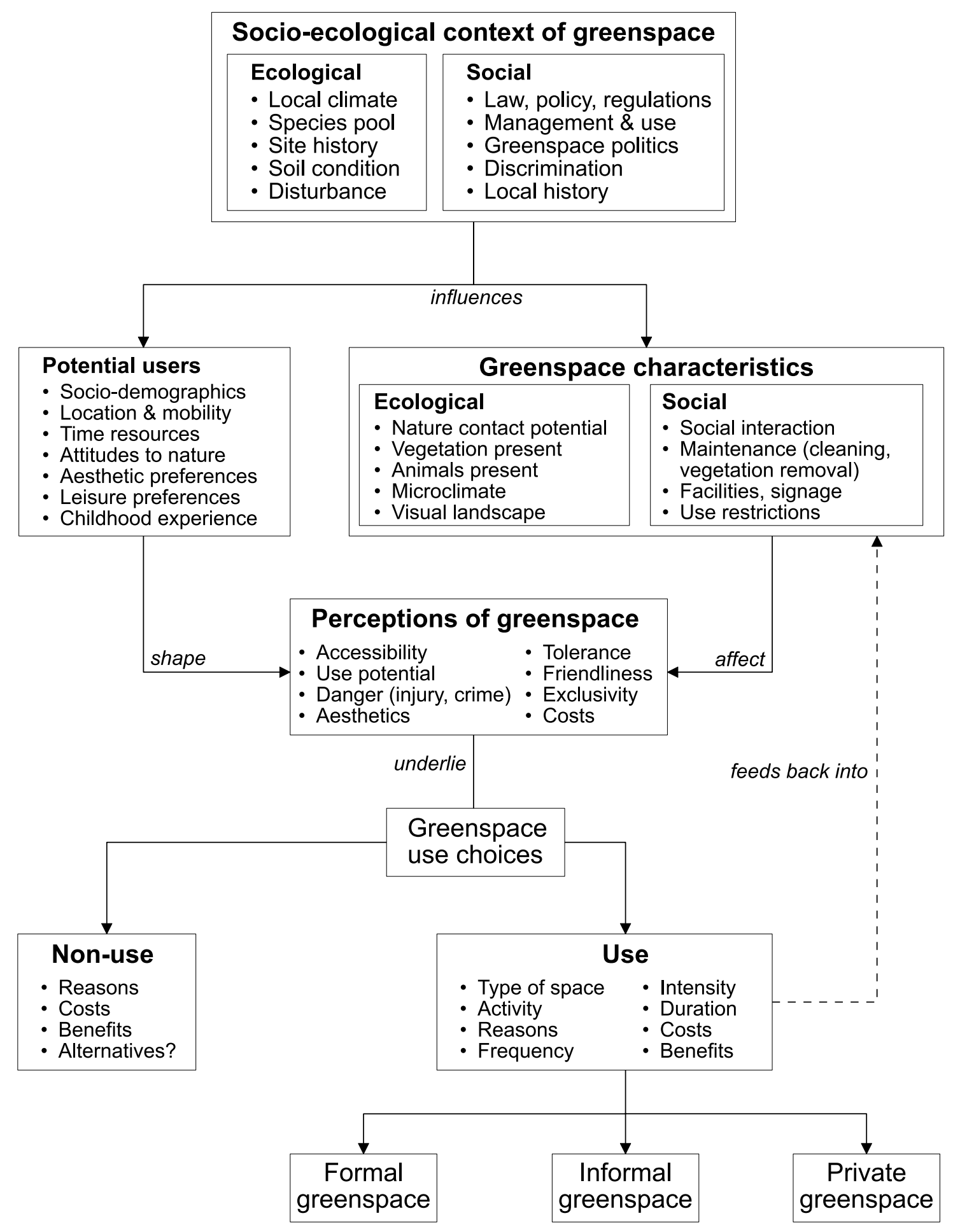

Figure 1 Conceptual model of factors influencing greenspace use choices

As we discuss above, the influence of natural elements on user preferences is particularly complex for IGS (Rupprecht \& Byrne, 2014b), which is why we include ecological characteristics of greenspace alongside social characteristics in the conceptual model. We 
have also added restrictions on utilization as an important element of social greenspace characteristics, because the lack of restrictions is potentially part of what makes IGS attractive (Campo, 2013). The central place of greenspace perception in our model recognizes how feelings of not-belonging can influence park use (Byrne, 2012) - an aspect that also applies to IGS due to its liminal nature (see above). We enriched the conceptual model with different types of greenspace to further draw attention to the heterogeneity of recreational greenspace options that are potentially available to urban residents. Finally, the comprehensive nature of our extended conceptual model allows us to consider the full complexity of factors involved in greenspace use decisions in our analysis.

\section{Methods}

\subsection{Definition of informal greenspace (IGS)}

For this study we have defined IGS as an explicitly socio-ecological rather than solely biological or cultural entity, following the definition we have employed elsewhere (Rupprecht \& Byrne, 2014a \& 2014b). IGS consists of any urban space with a history of strong anthropogenic disturbance that is covered at least partly with non-remnant, spontaneous vegetation. It is not formally recognized by governing institutions or property owners as greenspace designated for agriculture, forestry, gardening, recreation (either as parks or gardens), or for environmental protection (the typical purposes of most greenspace). Neither is the vegetation contained therein managed for any of these. IGSs differ in their management (e.g., access, vegetation removal, stewardship), land use and site history, their scale and shape, soil characteristics and local urban context. In this study we consider seven different subtypes of IGS: street verge (nature strip), vacant lot, brownfield, power line, railway verge, waterside and structural (Supplementary Material 1). Such a typology recognizes the variety of informal greenspace and provides a more useful conceptual basis to analyze the implications of IGS for recreation and planning than broad terms such as "wasteland" or "derelict land".

\subsection{Study area}

Brisbane (Queensland, Australia) and Sapporo (Hokkaidō, Japan) were selected as case study cities. As we describe elsewhere (Rupprecht \& Byrne, 2014a), these two cities have similarities and differences that enable comparison (Table 1). They provide excellent 
opportunities for cross-cultural research. Both cities are relatively young (being founded in the $19^{\text {th }}$ century) and they saw most of their growth during the $20^{\text {th }}$ century, especially in the post-second world-war period. Their close geographical size is complemented by a similar urban morphology. Both cities have planning systems that zone urban areas by land use, including greenspace areas designated for recreation. They are built around a dense core with outlying residential areas, are situated near to the coast and upland regions, and are bisected by a central river (Figure 2). These similarities contrast with differences in population density, population growth forecasts, and available parks and greenspace. While Sapporo has seen rapid growth throughout the second half of the $20^{\text {th }}$ century and currently has a population of about 1.9 million, its population is now stagnating and is predicted to decline in the future. In contrast, Brisbane has a population of around 1 million but is still growing relatively quickly (Table 1). This difference in population change is of particular interest as both expanding cities (Byrne et al., 2010) and shrinking cities (Haase, 2008) have important impacts on urban greenspace.

In both cities, formal greenspace consists of networks of over 2,000 public parks, many of them small local parks. Brisbane has 3,290 ha of local parkland $\left(32 \mathrm{~m}^{2} /\right.$ capita), whereas Sapporo has 2,345 ha (12.3 $\mathrm{m}^{2} /$ capita) (Table 1). All parks in Brisbane comprise an area of 11,840ha $\left(115 \mathrm{~m}^{2} /\right.$ capita $)$, while those in Sapporo combine to form an area of 5,508 ha (28.9 $\mathrm{m}^{2} /$ capita). Even though Sapporo has less greenspace, research has shown that residents form their image of Sapporo by perceiving its greenspaces in daily life (Ueda \& Rupprecht, 2014). These greenspaces include forested hillsides in the southwest of both cities, providing residents with additional recreation space. However, access to such spaces can be restricted due to bushfires in Brisbane (Queensland Government, Department of National Parks Recreation Sport and Racing, 2012) and bear sightings in Sapporo (Sapporo Kankyōkyoku Midori No Suishinbu, 2013). 
Table 1: Comparison of cities selected for case study

\begin{tabular}{|c|c|c|}
\hline & City of Brisbane (LGA) & Sapporo \\
\hline Founded & 1824 , city status 1902 & 1868 , city status 1922 \\
\hline Population & $1,089,743$ (2011) (2031: 1,27 million) & $\begin{array}{l}1,936,189 \text { (2013) (2030: } 1,87 \\
\text { million) }\end{array}$ \\
\hline Area & $1,338 \mathrm{~km}^{2}$ & $1,121.12 \mathrm{~km}^{2}$ \\
\hline Pop. density & $814 / \mathrm{km}^{2}$ & $1,699 / \mathrm{km}^{2}$ \\
\hline Peak density & $>5,000 / \mathrm{km}^{2}$ & $>8,000 / \mathrm{km}^{2}$ \\
\hline Climate & Humid subtropical (Cfa) & Humid continental (Dfa) \\
\hline Industry & $\begin{array}{l}\text { Tourism, resources, retail, financial } \\
\text { services, agriculture hub, education }\end{array}$ & $\begin{array}{l}\text { Tourism, retail, IT, agriculture hub, } \\
\text { resources, education }\end{array}$ \\
\hline Greenspace & $\begin{array}{l}\text { Local parks: } 3,290 \text { ha }\left(32 \mathrm{~m}^{2} / \text { capita }\right) \\
\text { All parks: } 11840 \text { ha }\left(115 \mathrm{~m}^{2} / \text { capita }\right)\end{array}$ & $\begin{array}{l}\text { Parks: } 2,345 \text { ha }\left(12.3 \mathrm{~m}^{2} / \text { capita }\right) \\
\text { All greenspace: } 5,508 \text { ha }(28.9 \\
\left.\mathrm{m}^{2} / \text { capita }\right)\end{array}$ \\
\hline $\begin{array}{l}\text { Park area } \\
\text { planned }\end{array}$ & $40 \mathrm{~m}^{2} /$ capita, minimum $20 \mathrm{~m}^{2} /$ capita & $\begin{array}{l}\text { "No greenspace loss, park } \\
\text { renovation" }\end{array}$ \\
\hline
\end{tabular}




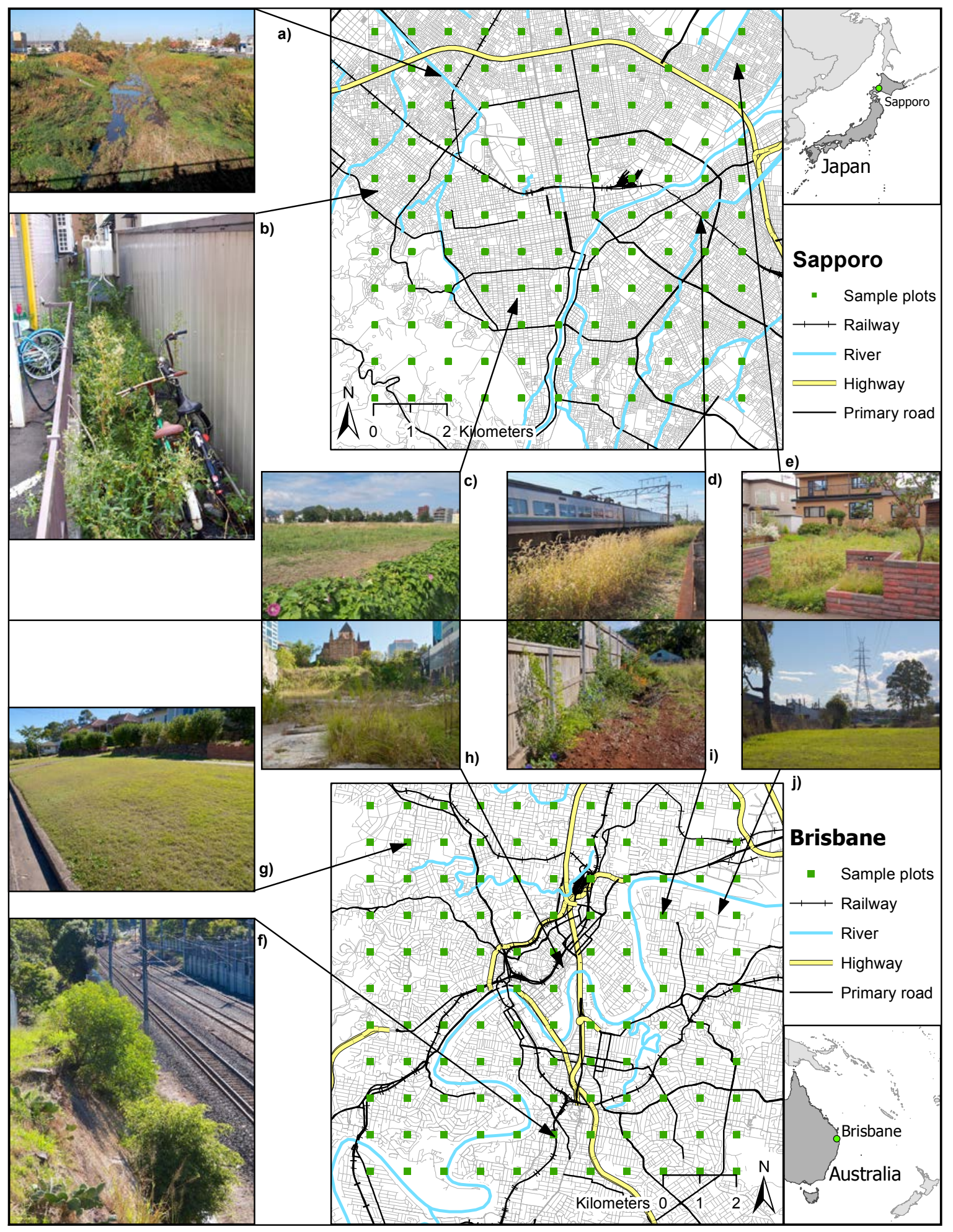

Figure 2 Map of Sapporo and Brisbane study areas with example IGS photographs. Sapporo: a) Waterside IGS on the banks of Shin River; b) Gap IGS used for informal storage; c) Large vacant brownfield IGS with structural IGS on fence in foreground; d) Railway IGS on verge next to rail track; e) Lot IGS on vacant residential lot, remains of garden present. Brisbane: f) Railway IGS on cliff next to rail track; g) Street verge IGS, unused and highly maintained; h) Inner-city brownfield IGS; i) Lot IGS on vacant residential lot with structural IGS on fence; j) Powerline IGS in industrial area. 


\subsection{Data collection}

Data collection was undertaken as part of a larger study on IGS (Rupprecht \& Byrne, 2014a; Rupprecht, Byrne \& Lo, 2015). A letterbox-drop, reply-paid mail-back questionnaire kit was distributed to a sample of 1,910 households in Brisbane and 1,980 in Sapporo (the small variation resulted from site accessibility). The households were located within a $400 \mathrm{~m}$ radius (easy walking distance) of 121 sampling sites (Figure 2). Questionnaires were only distributed at sites where IGS was located within a $400 \mathrm{~m}$ radius, to maximize potential respondents' IGS interaction. The 121 sampling sites were placed on the intersecting lines of a $10 \mathrm{~km}$ by $10 \mathrm{~km}$ grid centered on the city centers, using a systematic grid sampling design (Rupprecht \& Byrne, 2014a). There was a one-kilometer distance between any two adjacent sampling sites. This allowed us to cover most of the densely populated area (Rupprecht \& Byrne, 2014a). We devised the questionnaire distribution plan with the help of the home institution's research methodologist.

The questionnaire consisted of three parts: in the first part, residents were asked about their IGS perception, evaluation, and use. This section employed several multiple-choice questions and one open comment question (Veal, 2011). We asked respondents about IGS in their vicinity to learn how familiar they were with it from everyday life. Questions about IGS use were included so we could understand quantity and quality of IGS use, as well as respondents' reasons for using it. These questions included some on respondents' IGS use as children or teenagers, which we have discussed elsewhere (Rupprecht, Byrne \& Lo, 2015). To analyze the complex nexus of how respondents perceived and evaluated IGS, we opted for a three-pronged approach.

First, we asked respondents about perceived benefits (e.g., leisure, environmental) and problems related to IGS (e.g., aesthetic, security-related). Following these questions, which prompted respondents to consider positive and negative aspects of IGS, we enquired whether respondents thought IGS made their daily life better, worse, both, or whether they felt neutral about the issue. We used this question to capture a larger spectrum of respondents' evaluations than simpler questions might (e.g., 'better' or 'worse', Likert scale). Finally, we followed up by asking respondents to explain in their own words why they had chosen their answer in the previous question, and provided a $7 \mathrm{~cm}$ by $15 \mathrm{~cm}$ open comment box for this purpose (survey instrument available from first author on request). 
In the second part, nine five-point Likert scales (" 1 " representing "strongly agree" through "5" representing "strongly disagree") were used to measure agreement with statements on three topics: residents' disposition towards local greenspace; their knowledge of plants, animals and birds in their neighborhood; and the value of urban nature. Statements on the latter topic were derived from La Trobe and Acott's (2000) version of Dunlap's New Environmental Paradigm (NEP) question set (Dunlap, Van Liere, Mertig, \& Jones, 2000), and were modified to specifically address urban nature.

The last section contained socio-demographic questions. In Brisbane, this section also contained a question on the participant's racial/ethnic background, whereas in Sapporo the question asked where participants had grown up (given the ethno-racial homogeneity of Japan). The questionnaire kits included an IGS typology with color photography examples for every IGS type (see Supplementary Material 1). Additionally, the questionnaires started with a non-technical explanation of IGS and how it is different from formal greenspace to ensure respondents understood the definition of IGS we used. Open comment responses indicated participants could distinguish formal and informal greenspace. All material was initially written in English, then translated into Japanese and edited by native speakers to ensure it was correct and easy to read. The instrument was approved by the home institution's human subjects research ethics committee (ENV/28/12/HREC), and both versions were pilot tested. Minor variations were made to the questionnaires based on the feedback received, including modifying the consent instrument in Japan to accommodate cultural differences.

To avoid bias in the selection of households, we distributed survey kits by walking from the site center, starting in westerly direction (if possible; north, east, or south in this order if the previous direction was unavailable), taking a right turn at every corner, but avoiding already walked streets. Survey kits were distributed to every residential letterbox, but body corporate letterboxes and vacant residential dwellings were skipped. In Brisbane, respondents had the additional option of completing the questionnaire online, but this option was dropped in Sapporo because distribution was combined with a second questionnaire on the role of greenspace for the image of the city (Ueda \& Rupprecht, 2014), for which online completion was technically not feasible. 


\subsection{Data analysis}

To analyze the quantitative data, we used SPSS (v. $21 \& 22$, OSX) to perform descriptive and inferential statistical analyses. Frequency tables were used to describe respondents' perception, evaluation, and use of IGS. Initial analyses indicated that the sample data was not normally distributed (P-P plots, skewness and kurtosis tests). Following Field (2009), we therefore chose non-parametric statistical tests (Spearmann correlation, Kruskal-Wallis, Mann-Whitney U, point-biserial correlation, Chi-square/Fisher's exact) to analyze factors influencing respondents' evaluation and use of IGS. Mann-Whitney U tests were also used to test for significant differences between the two samples. As we conducted a self-selected mail-back survey without asking for information that would allow identification of households (a condition of the research ethics approval), and because census data is not accessible for individual households, we were unable to determine the socio-demographic characteristics of non-respondents and thus could not check non-response data for potential bias. Instead, we compared the demographic characteristics of our samples with city-level population census data from Brisbane and Sapporo to check the representativeness of the samples. A p-value of 0.05 or smaller was interpreted as the significance limit.

For the qualitative data, open-ended comments provided by the respondents in the instrument section on IGS appreciation were qualitatively analyzed using coding and content analysis to identify key concepts (Sproule 2006). In the first round, all comments were screened and categorized based on their main topic (e.g., 'Concerns', 'IGS use') with implicit coding (Sproule 2006). We then identified key concepts (e.g. 'aesthetics', 'future use') employing a conceptual content analysis approach (Sproule 2006). Based on these key concepts, the comments were drawn upon to provide a qualitative context when discussing the quantitative results of the survey. For direct quotations, respondents were assigned pseudonyms, chosen from popular names during their time of birth in their respective cultures, to protect anonymity.

To understand whether residents used IGS merely as a substitute for formal (and thus more maintained) greenspace, we examined the possible influence that formal greenspace within walking distance of residents' dwellings might have upon their use of IGS, IGS evaluation, and reported number of IGSs in their neighborhoods. We used ArcGIS (v. 10.1) to perform a buffer analysis to measure the amount of formal greenspace within a 500m radius around the 
sampling sites. This data was extracted from formal greenspace datasets provided by the Brisbane Council and the Sapporo Department of Environment. Responses were assigned to sampling sites based on the name of the nearest road intersection that residents reported, and were used to calculate values for IGS use, evaluation and number of IGS for each sampling site. We then used Spearmann and point-biserial correlation analysis to test for possible relationships.

\section{Results}

\subsection{Sample characteristics}

A total of 123 valid responses (11 online) were collected in Brisbane, 163 in Sapporo (response rate: Brisbane 6.4\%, Sapporo 8.2\%). Five responses in Brisbane and seven in Sapporo were classified as invalid (e.g., questionnaires returned empty or with only one question answered; valid response rate: Brisbane 96.1\%, Sapporo 95.9\%). Brisbane and Sapporo samples show some differences (Table 2). Significant differences are demonstrated using nonparametric tests for all demographic variables other than sex. Respondents in Sapporo are older than in Brisbane, have lower income and lower levels of tertiary education, and fewer live in houses with a garden. Compared to general population census data from their respective cities, respondents in both cities tend to be older and include a lower percentage of the sub-\$25k/ $¥ 2$ million annual household income bracket (lower income earners) and a higher percentage of the over-\$150k/ $¥ 12.5$ million bracket (higher income earners). The percentages of respondents who had not finished high school are lower in comparison to the overall city population, while the percentages of respondents with university degrees are higher. Brisbane respondents include more women than the city average. In Brisbane, 94\% of respondents identified themselves as White, Caucasian or European, while the remaining responses include Asian, Aboriginal or Torres Straits Islander, or declined to answer. In Sapporo, 36\% of respondents grew up in Sapporo, $45 \%$ grew up in other areas of Hokkaidō, and the remaining respondents (19\%) grew up in other areas of Japan. 
Table 2: Sample population characteristics and comparison with census data

\begin{tabular}{|c|c|c|c|c|c|c|}
\hline \multirow[t]{2}{*}{ Variables } & & \multicolumn{2}{|c|}{ Brisbane (LGA) } & \multicolumn{2}{|c|}{ Sapporo } & \multirow[t]{2}{*}{$\mathbf{p}^{*}$} \\
\hline & & City & Sample & City & Sample & \\
\hline Age & Median & 34 & 54 & 45 & 58 & $<0.05$ \\
\hline Sex & Females (\%) & 50.7 & 62.7 & 53.0 & 53.2 & n. s. \\
\hline Education & Did not finish high school & 10.5 & 2.5 & 11.0 & 3.8 & \\
\hline \multirow[t]{2}{*}{ (in \%) } & High school & 25.1 & 18.6 & 36.6 & 42.5 & \multirow[t]{2}{*}{$<0.001$} \\
\hline & University & 30.7 & 78.9 & 32.2 & 53.8 & \\
\hline \multirow{8}{*}{$\begin{array}{l}\text { Income } * * \\
\text { (annual house- } \\
\text { hold, in \%) }\end{array}$} & Less than $\$ 25 \mathrm{k} / ¥ 2$ million & 18.1 & 5.8 & 21.7 & 11.2 & \multirow{8}{*}{$<0.001$} \\
\hline & $\$ 25 \mathrm{k}-\$ 50 \mathrm{k} / ¥ 2-4$ million & 14.7 & 13.2 & 32.2 & 34.2 & \\
\hline & $\$ 50 \mathrm{k}-\$ 75 \mathrm{k} / ¥ 4-6$ million & 15.9 & 13.2 & 19.0 & 15.5 & \\
\hline & $\$ 75 \mathrm{k}-\$ 100 \mathrm{k} / ¥ 6-8$ million & 13.1 & 13.2 & 9.8 & 14.3 & \\
\hline & $\$ 100 \mathrm{k}-\$ 125 \mathrm{k} / ¥ 8-10$ million & 10.4 & 9.1 & 6.2 & 6.8 & \\
\hline & $\$ 125 \mathrm{k}-\$ 150 \mathrm{k} / ¥ 10-12.5$ million & 11.5 & 13.2 & 3.6 & 2.5 & \\
\hline & $>\$ 150 \mathrm{k} / ¥ 12.5$ million & 16.3 & 21.5 & 3.4 & 2.5 & \\
\hline & Do not wish to answer & & 10.70 & & 13.0 & \\
\hline \multirow[t]{4}{*}{$\begin{array}{l}\text { Housing } \\
(\text { in } \%)\end{array}$} & $\begin{array}{l}\text { House (detached, duplex, } \\
\text { town/row/terrace house) with garden }\end{array}$ & & 81.3 & & 54.7 & \multirow{4}{*}{$<0.001$} \\
\hline & $\begin{array}{l}\text { House (detached, duplex, } \\
\text { town/row/terrace house) without garden }\end{array}$ & & 2.4 & & 4.3 & \\
\hline & Apartment or unit with shared greenspace & & 10.6 & & 9.9 & \\
\hline & $\begin{array}{l}\text { Apartment or unit without shared } \\
\text { greenspace }\end{array}$ & & 5.7 & & 31.1 & \\
\hline
\end{tabular}

*Significant difference level between Brisbane and Sapporo questionnaire sample means using MannWhitney U tests.

**Note: Brisbane City income categories do not correspond exactly with the categories used in the table (vary between $+\$ 600$ for lowest category and $+\$ 6000$ for highest category).

Sources: Australian Bureau of Statistics, Sapporo City Statistics Department

According to the mean ratings of the nine disposition questions (Table 3), respondents generally desired more greenspace in their neighborhood and highly valued it. They did not see themselves as very knowledgeable about local nature. Most respondents had proenvironmental value orientations (La Trobe \& Acott, 2000). While respondents were hesitant in their willingness to contribute money to urban nature preservation, they agreed that urban nature is valuable. They also agreed that people have an obligation to preserve urban nature for future generations, and agreed that urban animals and plants have as much right as humans to exist. Except for the statements regarding the intrinsic value of urban nature and the contribution of money for its preservation, Brisbane respondents agreed significantly more with the value statements than did those in Sapporo (Table 3). 
Table 3: Means of residents' views on close greenspace, their knowledge about nature, and disposition towards urban nature

\begin{tabular}{|c|c|c|c|c|}
\hline \multirow{3}{*}{$\begin{array}{l}\text { Topic } \\
\text { Greenspace in } \\
\text { neighborhood } \\
\end{array}$} & \multirow{2}{*}{$\begin{array}{l}\text { Questions asked }(\mathbf{1}=\text { str. agree, } \mathbf{5}=\text { str. } \text { disagree }) \\
\text { There should be more green space in my neighborhood. }\end{array}$} & \multicolumn{2}{|c|}{ Brisbane Sapporo } & \multirow{2}{*}{$\frac{\mathbf{p}^{*}}{<0.01}$} \\
\hline & & 2.11 & 2.40 & \\
\hline & The green space in my neighborhood is very important to me. & 1.68 & 1.85 & $<0.05$ \\
\hline \multirow{3}{*}{$\begin{array}{l}\text { Knowledge abou } \\
\text { neighborhood } \\
\text { nature }\end{array}$} & I know a lot about the wild plants in my neighborhood. & 3.1 & 3.71 & $<0.001$ \\
\hline & I kno & 2.84 & 3.67 & $<0.001$ \\
\hline & I know a lot about the birds in & 2.75 & 3.66 & $<0.001$ \\
\hline \multirow{4}{*}{$\begin{array}{l}\text { Attitude towards } \\
\text { urban nature } \\
\text { (derived from } \\
\text { NEP) }\end{array}$} & $\begin{array}{l}\text { Urban nature has value within itself, regardless of any value } \\
\text { humans may place on it. }\end{array}$ & 1.66 & 1.76 & n.s. \\
\hline & $\begin{array}{l}\text { We have an obligation to preserve urban nature for future } \\
\text { generations. }\end{array}$ & 1.60 & 1.66 & n.s. \\
\hline & 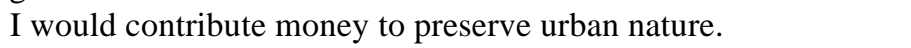 & & 2.92 & $<0.001$ \\
\hline & $\begin{array}{l}\text { Urban animals and plants have as much right as humans to } \\
\text { exist. }\end{array}$ & 2.04 & 2.31 & $<0.01$ \\
\hline
\end{tabular}

* Significant difference level between Brisbane and Sapporo sample means using Mann-Whitney U tests.

\subsection{Respondents' perception, evaluation and use of IGS}

Most respondents in Brisbane (91.9\%) and Sapporo (82.1\%) knew of at least one to five IGS sites in their neighborhood (Table 4). The most commonly known IGS types in both cities were vacant lots, riverbanks and road verges (Table 4). Brisbane respondents knew of more IGS in their neighborhood, and mentioned several IGS types significantly more frequently than respondents in Sapporo did (Table 4). Over $40 \%$ of respondents in both cities believed many or very many species of animals and plants live in IGS.

Table 4: IGS knowledge and perception

\begin{tabular}{llrrr} 
Question asked & Responses & Brisbane & Sapporo & p* \\
& & \% & \% & \\
\hline How many informal & None & 5.1 & 17.9 & $<0.001$ \\
greenspaces do you know & Few (1-5) & 52.0 & 61.1 & \\
of in your neighborhood? & Some (5-10) & 27.6 & 16.0 & \\
(Please check only one) & Many (over 10) & 12.2 & 4.9 & \\
\hline What kind of informal & Railway tracks & $\mathbf{4 4 . 2}$ & 11.7 & $<0.001$ \\
greenspace do you know of & Overgrown walls or fences & $\mathbf{4 2 . 5}$ & 26.3 & $<0.01$ \\
in your neighborhood? & Trails, foot paths & $\mathbf{5 2 . 2}$ & 33.6 & $<0.01$ \\
Please check only those & Roofs with wild plants & $\mathbf{1 5 . 0}$ & 5.1 & $<0.01$ \\
places that have vegetation & River banks & $\mathbf{6 5 . 5}$ & 55.5 & $<.05$ \\
but are not parks, gardens & Vacant or abandoned lots & 71.7 & 76.6 & n.s. \\
or remnant bushland etc. & Road verges & 61.1 & 54.0 & n.s. \\
(Please check all that & Brownfields (former industrial areas) & 19.5 & 15.3 & n.s. \\
apply) & Power line corridors & 15.9 & 15.3 & n.s. \\
& Other & 7.1 & 4.4 & n.s. \\
\hline
\end{tabular}

\footnotetext{
* Significant difference level between the two samples, bold numbers represent sample with higher
} percentage.

The most frequently reported potential benefits of IGS (Table 5) were provision of wildlife habitat in Brisbane (89.3\%) and contribution to city greenspace in Sapporo (67.1\%). Other commonly perceived benefits included the air filtration and oxygen production provided by 
plants in IGS, the pleasure of looking at grasses, trees and flowers in IGS, and the opportunities for play and nature experience it can provide to children. Brisbane respondents reported all IGS benefits significantly more frequently. In contrast, the most frequently reported potential problems of IGS (Table 5) in Brisbane were littering (87.1\%), vandalism, weed infestation and graffiti. In Sapporo, littering (90.9\%), weed infestation, unkempt visual appearance, and IGS as a source of pest animals were most frequently reported (Table 5). When asked if IGS "made their daily life better, worse, both or neutral", the majority of respondents in Brisbane answered "better" (64.8\%) followed by "neutral" (18.9\%), compared with "both" (47.1\%) followed by "neutral" (27.1\%) in Sapporo (Figure 3).

Table 5: Perceived potential benefits and problems of IGS

\begin{tabular}{|c|c|c|c|c|}
\hline Question asked & Response options & $\begin{array}{r}\text { Brisbane } \\
\% \\
\end{array}$ & $\begin{array}{r}\text { Sapporo } \\
\% \\
\end{array}$ & $\mathbf{p}^{*}$ \\
\hline \multirow{18}{*}{$\begin{array}{l}\text { What kind of } \\
\text { benefits do you } \\
\text { think informal } \\
\text { greenspace can } \\
\text { have? }\end{array}$} & The grasses, trees and flowers are nice to look at & 73.0 & 46.2 & $<0.001$ \\
\hline & Wildlife can live in them & 89.3 & 38.6 & $<0.001$ \\
\hline & It makes the neighborhood more interesting & 66.4 & 24.1 & $<0.001$ \\
\hline & It can be used for leisure activities & 46.7 & 16.5 & $<0.001$ \\
\hline & The plants filter the air and produce oxygen & 73.8 & 48.7 & $<0.001$ \\
\hline & It provides a place for nature experience & 57.4 & 35.4 & $<0.001$ \\
\hline & It provides a place to relax & 38.5 & 26.6 & $<.05$ \\
\hline & It provides a place to escape the city & 45.1 & 13.9 & $<0.001$ \\
\hline & We can grow food & 31.1 & 3.8 & $<0.001$ \\
\hline & We can find food (wild herbs, berries etc.) & 22.1 & 9.5 & $<0.01$ \\
\hline & Children can use it to play & 53.3 & 38.0 & $<0.01$ \\
\hline & Children can experience nature in the city & 67.2 & 27.8 & $<0.001$ \\
\hline & The green space helps to cool the city & 54.1 & 35.4 & $<0.01$ \\
\hline & $\begin{array}{l}\text { The plants help to capture carbon and mitigate } \\
\text { climate change }\end{array}$ & 58.2 & 17.7 & $<0.001$ \\
\hline & $\begin{array}{l}\text { The plants and animals contribute to urban } \\
\text { biodiversity }\end{array}$ & 67.2 & 23.4 & $<0.001$ \\
\hline & Great chance to observe birds and other wildlife & 62.3 & 34.2 & $<0.001$ \\
\hline & Every bit of green in the city is good & 74.6 & 67.1 & n.s. \\
\hline & Other & 7.4 & 3.2 & n.s. \\
\hline \multirow{16}{*}{$\begin{array}{l}\text { What kind of } \\
\text { problems do you } \\
\text { think informal } \\
\text { greenspace can } \\
\text { pose? }\end{array}$} & Waste of space and should be developed & 5.2 & 9.1 & n.s. \\
\hline & Littering & 87.1 & 90.9 & n.s. \\
\hline & Vandalism & 57.8 & 17.5 & $<0.001$ \\
\hline & Graffiti & 48.3 & 18.2 & $<0.001$ \\
\hline & Children and teenagers there make noise & 3.4 & 5.8 & n.s. \\
\hline & Criminals may use it & 29.3 & 25.3 & n.s. \\
\hline & Looks filthy and unorderly & 26.7 & 42.9 & $<0.01$ \\
\hline & Unsafe for children & $\mathrm{n} / \mathrm{a}$ & 27.3 & $\mathrm{n} / \mathrm{a}$ \\
\hline & Breeding ground for pest animals & 38.8 & 35.7 & n.s. \\
\hline & Full of weeds & 57.8 & 59.1 & n.s. \\
\hline & Attracts unwanted individuals & 31.9 & 30.5 & n.s. \\
\hline & Fire hazard & 21.6 & 15.6 & n.s. \\
\hline & Prostitutes may use it & 7.8 & 1.9 & $<.05$ \\
\hline & Gangs may use it & 13.8 & 3.9 & $<0.01$ \\
\hline & Liability (e.g. insurance) conflicts & 9.5 & 14.9 & n.s. \\
\hline & Other & 8.6 & 1.9 & $<.05$ \\
\hline
\end{tabular}

* Significant difference level between the two samples, bold numbers represent sample with higher percentage. 


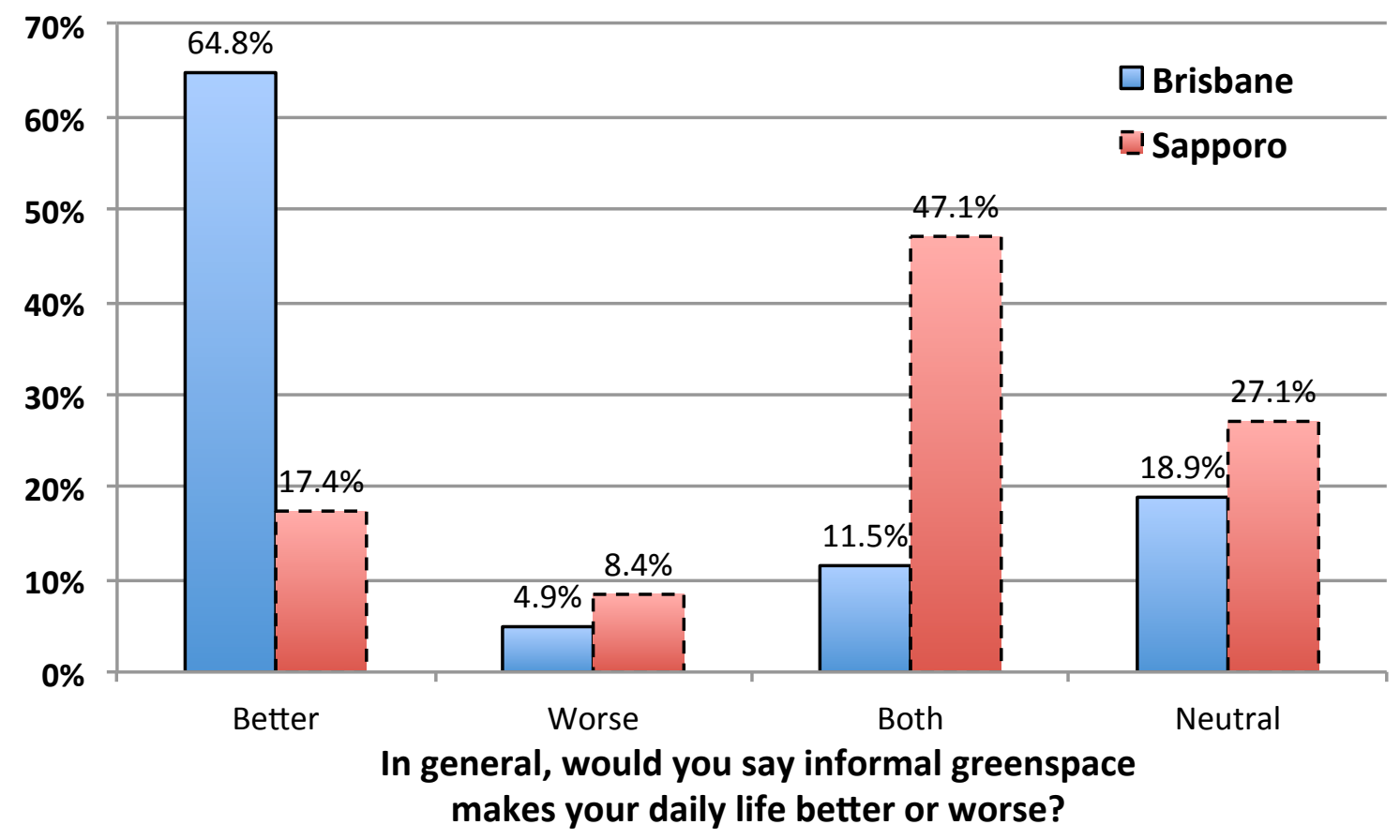

Figure 3 Respondents' evaluation of IGS influence on daily life

More than half of the respondents used IGS for recreational activities in Brisbane (52.2\%), and almost a third (30.7\%) in Sapporo (Figure 4) - a significant difference between the two samples. In contrast, use frequency did not significantly differ between the two cities, as more than half of the respondents used IGS daily or weekly in Brisbane (62.7\%) and more than a third (40.5\%) in Sapporo (Figure 4). The most popular activities were walking $(81.4 \%)$, enjoying the view (49.2\%) and dog walking (33.9\%) in Brisbane, and walking $(60.5 \%)$, enjoying the view (32.6\%) and wildlife or plant observation (23.3\%) in Sapporo (Table 6). Walking and exploring were the only activities with significant differences between the two cities, and both were more popular in Brisbane. The most common reasons why respondents in both Brisbane and Sapporo used IGS instead of a park or garden was because it was near their home $(87.9 \%$ and $75.0 \%$ respectively), was not crowded $(44.8 \%$, $30.0 \%)$, had more or different animals or plants $(31.0 \% ; 22.5 \%)$, and had no use restrictions (e.g., "no dogs"; "no ball play") (24.1\%; 20.0\%; Table 6). Most respondents in Brisbane (78.6\%) and Sapporo (81.4\%) had not experienced any problems while using IGS. When respondents reported issues, the most commonly reported were litter $(10.7 \%$ of respondents in Brisbane, $18.6 \%$ in Sapporo) followed by risk of injury (5.4\% and $11.6 \%$ respectively; Table 6). 


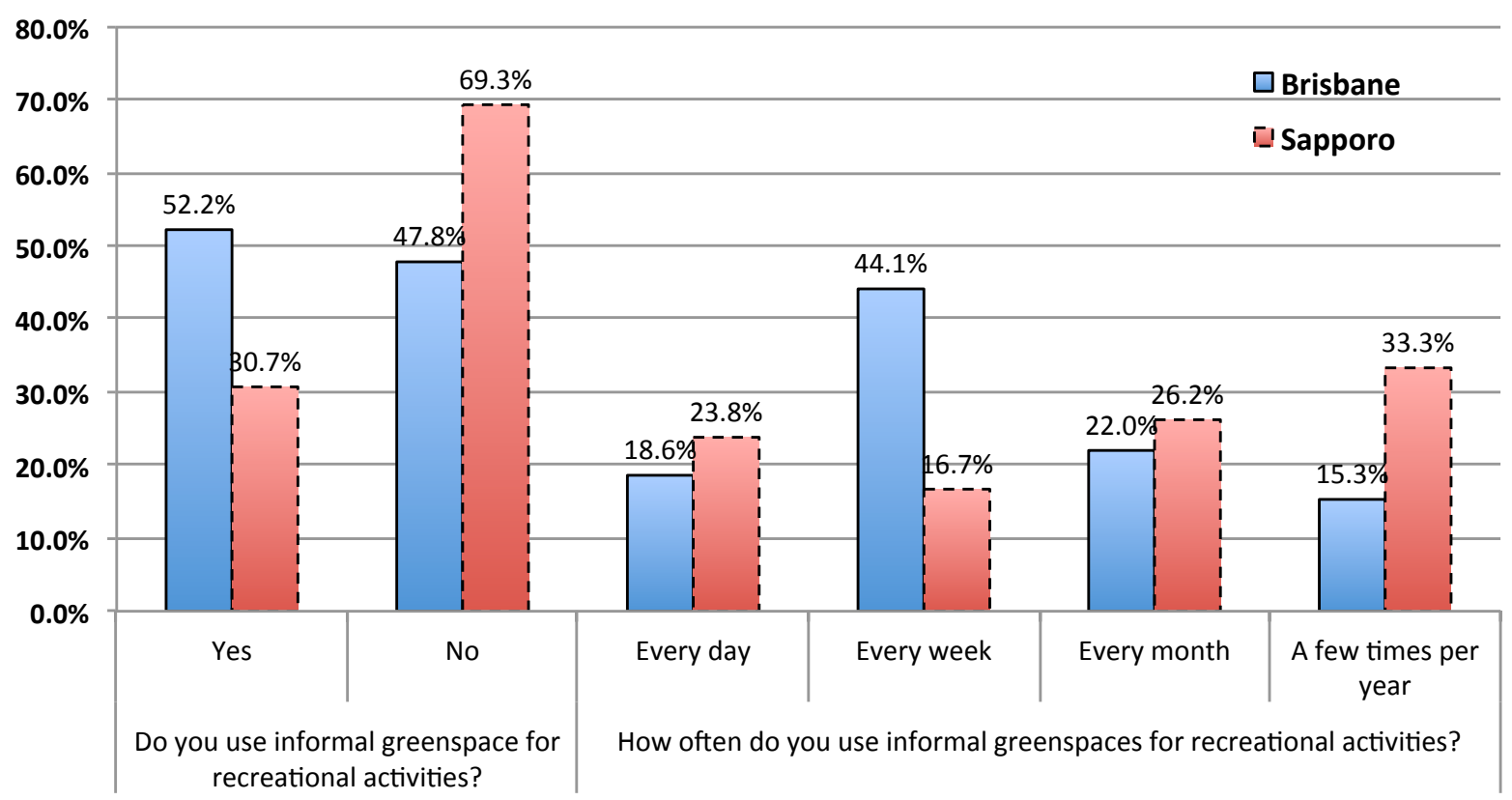

Figure 4 Respondents' use and use frequency of IGS 
Table 6: Activities, reasons for use, and problems related to IGS use

\begin{tabular}{|c|c|c|c|c|}
\hline Question asked & Response options & $\begin{array}{c}\text { Brisbane } \\
\% \\
\end{array}$ & $\begin{array}{c}\text { Sapporo } \\
\% \\
\end{array}$ & p* \\
\hline \multirow{20}{*}{$\begin{array}{l}\text { What kind of } \\
\text { activities do you } \\
\text { use informal } \\
\text { greenspace for? }\end{array}$} & Walking & 81.4 & 60.5 & $<0.05$ \\
\hline & Picnicking & 8.5 & 0.0 & n.s. \\
\hline & Mountain biking/BMX & 6.8 & 2.3 & n.s. \\
\hline & Photography & 6.8 & 11.6 & n.s. \\
\hline & Wildlife or plant observation & 28.8 & 23.3 & n.s. \\
\hline & Enjoying the view & 49.2 & 32.6 & n.s. \\
\hline & Educate children about nature & 13.6 & 4.7 & n.s. \\
\hline & Escape the city & 11.9 & 4.7 & n.s. \\
\hline & Exploring (including urban exploration) & 16.9 & 0.0 & $<0.01$ \\
\hline & Walking $\operatorname{dog}(\mathrm{s})$ & 33.9 & 20.9 & n.s. \\
\hline & Outdoor games and sports & 11.9 & 20.9 & n.s. \\
\hline & Sunbathing & 0.0 & 9.3 & n.s. \\
\hline & Dancing & 0.0 & 2.3 & n.s. \\
\hline & Reading & 3.4 & 2.3 & n.s. \\
\hline & Tai Chi, Yoga etc. & 1.7 & 2.3 & n.s. \\
\hline & Hanging out & 10.2 & 7.0 & n.s. \\
\hline & Growing vegetables & 5.1 & 0.0 & n.s. \\
\hline & Growing flowers or other plants except vegetables & 5.1 & 7.0 & n.s. \\
\hline & Treasure hunting (looking for items) & 5.1 & 2.3 & n.s. \\
\hline & Other & 6.8 & 11.6 & n.s. \\
\hline \multirow{10}{*}{$\begin{array}{l}\text { Why do you use } \\
\text { informal } \\
\text { greenspace and } \\
\text { not a park or } \\
\text { garden? }\end{array}$} & It's near my home & 87.9 & 75.0 & $<0.05$ \\
\hline & It's wild and exciting & 22.4 & 10.0 & n.s. \\
\hline & It's not crowded & 44.8 & 30.0 & n.s. \\
\hline & There are more or different animals or plants & 31.0 & 22.5 & n.s. \\
\hline & It has better privacy (nobody watching) & 5.2 & 5.0 & n.s. \\
\hline & $\begin{array}{l}\text { There are no use restrictions (e.g. no dogs, no ball } \\
\text { play) }\end{array}$ & 24.1 & 20.0 & n.s. \\
\hline & It can be used for many things (e.g. gardening) & 12.1 & 0.0 & $<0.05$ \\
\hline & There are no nice parks near my home & 10.3 & 15.0 & n.s. \\
\hline & I don't have a garden or similar greenspace & 12.1 & 12.5 & n.s. \\
\hline & Other & 13.8 & 5.0 & n.s. \\
\hline \multirow{9}{*}{$\begin{array}{l}\text { Do you } \\
\text { experience any } \\
\text { problems when } \\
\text { using informal } \\
\text { greenspace? }\end{array}$} & I have not experienced problems & 78.6 & 81.4 & n.s. \\
\hline & Hard to access (fence, signs etc.) & 5.4 & 2.3 & n.s. \\
\hline & I am scared to use it & 1.8 & 2.3 & n.s. \\
\hline & Dangerous animals & 1.8 & 0.0 & n.s. \\
\hline & Dangerous plants & 1.8 & 0.0 & n.s. \\
\hline & Danger of injury & 5.4 & 11.6 & n.s. \\
\hline & Lots of litter & 10.7 & 18.6 & n.s. \\
\hline & Conflict with other users & 1.8 & 0.0 & n.s. \\
\hline & Other & 5.4 & 7.0 & n.s. \\
\hline
\end{tabular}

*Of difference between the two samples, bold numbers represent sample with higher percentage.

\subsection{Factors influencing respondents' IGS evaluation and use}

Tests suggest that demographic characteristics (sex, age, income and education) had only limited influence on respondents' evaluation and use of IGS (Table 7). Sex of the respondents is not correlated with IGS evaluation, use or use frequency in either city. Age of the respondents is not correlated with IGS evaluation or use frequency, but it is positively 
correlated with the use of IGS in both cities. Income and level of educational attainment are not correlated with IGS evaluation, use, or use frequency in either city. IGS users evaluated IGS significantly more positively in both cities (Table 7). The only difference in the influence of demographic factors between the cities is a larger effect size in the Sapporo sample for the correlations between respondent age and IGS use, as well as IGS use and IGS evaluation. In Brisbane, the sample size for non-White respondents is too small to test for differences between ethno-racial groups.

Table 7: Influence factors of IGS evaluation and use

\begin{tabular}{|c|c|c|c|c|}
\hline Predictor & Outcome variable & Analysis type & Brisbane Results & Sapporo Results \\
\hline \multirow[t]{4}{*}{ Sex } & IGS evaluation & Mann-Whitney U & n.s. & n.s. \\
\hline & $\begin{array}{l}\text { IGS evaluation } \\
\text { (unranked) }\end{array}$ & Chi-square & n.s. & n.s. \\
\hline & IGS use & Chi-square & n.s. & n.s. \\
\hline & IGS use frequency & Mann-Whitney U & n.s. & n.s. \\
\hline \multirow[t]{3}{*}{ Age } & IGS evaluation & Spearmann rho & n.s. & n.s. \\
\hline & IGS use & Point-biserial & positive $^{*}\left(\mathrm{r}_{\mathrm{pb}}=-.194\right)$ & positive $^{* *}\left(\mathrm{r}_{\mathrm{pb}}=-.290\right)$ \\
\hline & IGS use frequency & Spearmann rho & n.s. & n.s. \\
\hline \multirow[t]{3}{*}{ Income } & IGS evaluation & Kruskal-Wallis & n.s. & n.s. \\
\hline & IGS use & Fisher's Exact & n.s. & n.s. \\
\hline & IGS use frequency & Kruskal-Wallis & n.s. & n.s. \\
\hline \multirow[t]{3}{*}{ Education } & IGS evaluation & Kruskal-Wallis & n.s. & n.s. \\
\hline & IGS use & Fisher's Exact & n.s. & n.s. \\
\hline & IGS use frequency & Kruskal-Wallis & n.s. & n.s. \\
\hline Use & IGS evaluation & Mann-Whitney U & $\begin{array}{l}\text { positive** }(r=-0.273 \\
Z=-2.633, U=832.00 \\
N=93)\end{array}$ & $\begin{array}{l}\text { positive** }(r=-0.351, \\
\mathrm{Z}=-3.460, \mathrm{U}=634.50 \\
\mathrm{~N}=97)\end{array}$ \\
\hline
\end{tabular}

Note: $*$ denotes significance level of $\mathrm{p}<.05$, ** denotes significance level of $\mathrm{p}<.01$, n.s. denotes 'not significant' at the $\mathrm{p}<.05$ level. $\mathrm{r}_{\mathrm{pb}}$ denotes the effect strength of the point-biserial correlation.

For our spatial analysis, the area of formal greenspace within $500 \mathrm{~m}$ of the respective sampling sites does not significantly correlate with IGS use, nor does it correlate with IGS evaluation or the number of IGS reported in the neighborhood in either city ( $p>.05$ for all correlation analyses). We will discuss the implications of this finding later in the paper.

IGS evaluation and use is linked with respondents' environmental disposition and selfreported knowledge of local nature in a variety of ways (Table 8). Desire for more greenspace is correlated with higher IGS evaluation in both cities (Brisbane $r=.28$; Sapporo $\mathrm{r}=.19)$. The importance of neighborhood greenspace is correlated with higher IGS evaluation and use in both cities (Brisbane: $\mathrm{r}=.42, \mathrm{r}=.29$; Sapporo: $\mathrm{r}=.22, \mathrm{r}=.3$ ). IGS use is correlated with self-reported knowledge of plants and birds in the neighborhood in Brisbane $(r=.25$, $\mathrm{r}=.3$ ), but only with plant knowledge in Sapporo $(\mathrm{r}=.22)$. Self-reported knowledge of plants, 
animals, and birds is correlated with IGS evaluation in Sapporo ( $\mathrm{r}=.22, \mathrm{r}=.27, \mathrm{r}=.23$ ), but not in Brisbane. Stronger agreement with the statement that urban nature possesses intrinsic value is correlated with higher IGS evaluation in both cities (Brisbane $r=.4$; Sapporo $r=.19$ ). A sense of obligation to preserve urban nature for future generations is correlated with higher IGS evaluation only in Brisbane ( $\mathrm{r}=.35)$. Willingness to contribute money for urban nature preservation is highly correlated with higher IGS evaluation in both cities (Brisbane $\mathrm{r}=.34$; Sapporo $\mathrm{r}=.29$ ). The belief that urban animals and plants have as much right as humans to exist is also correlated with higher IGS evaluation in both cities (Brisbane $r=.29$; Sapporo $\mathrm{r}=.2$; Table 8).

Table 8: Correlation of attitude factors with IGS evaluation and use

\begin{tabular}{|c|c|c|c|c|c|}
\hline \multirow{4}{*}{$\begin{array}{l}\text { Topic } \\
\text { Greenspace in } \\
\text { neighborhood }\end{array}$} & \multirow{3}{*}{$\begin{array}{l}\text { Correlation variables } \\
\text { There should be more } \\
\text { green space in my } \\
\text { neighborhood. }\end{array}$} & \multicolumn{2}{|c|}{ Sapporo } & \multicolumn{2}{|c|}{ Brisbane } \\
\hline & & IGS Evaluation & IGS Use & IGS Evaluation & IGS Use \\
\hline & & positive* $^{*}(\mathrm{r}=.19)$ & n.s. & positive** $(\mathrm{r}=.28)$ & n.s. \\
\hline & $\begin{array}{l}\text { The green space in my } \\
\text { neighborhood is very } \\
\text { important to me. }\end{array}$ & positive $^{*}(\mathrm{r}=.22)$ & $\begin{array}{l}\text { positive** } \\
\quad(\mathrm{r}=.3)\end{array}$ & positive $^{* *}(\mathrm{r}=.42)$ & positive $^{* *}(\mathrm{r}=.29)$ \\
\hline \multirow{3}{*}{$\begin{array}{l}\text { Knowledge } \\
\text { about } \\
\text { neighborhood } \\
\text { nature }\end{array}$} & $\begin{array}{l}\text { I know a lot about the } \\
\text { wild plants in my } \\
\text { neighborhood. }\end{array}$ & positive $^{*}(\mathrm{r}=.22)$ & $\begin{array}{c}\text { positive* } \\
(\mathrm{r}=.22)\end{array}$ & n.s. & positive $^{* *}(\mathrm{r}=.25)$ \\
\hline & $\begin{array}{l}\text { I know a lot about the } \\
\text { wild animals in my } \\
\text { neighborhood. }\end{array}$ & $\begin{array}{l}\text { positive** } \\
(\mathrm{r}=.27)\end{array}$ & n.s. & n.s. & n.s. \\
\hline & $\begin{array}{l}\text { I know a lot about the } \\
\text { birds in my } \\
\text { neighborhood. }\end{array}$ & positive $^{*}(\mathrm{r}=.23)$ & n.s. & n.s. & $\operatorname{positive}^{* *}(\mathrm{r}=.3)$ \\
\hline \multirow[t]{4}{*}{$\begin{array}{l}\text { Attitude } \\
\text { towards urban } \\
\text { nature (derived } \\
\text { from NEP) }\end{array}$} & $\begin{array}{l}\text { Urban nature has value } \\
\text { within itself, regardless } \\
\text { of any value humans } \\
\text { may place on it. }\end{array}$ & positive* $^{*}(\mathrm{r}=.19)$ & n.s. & positive** $(\mathrm{r}=.4)$ & n.s. \\
\hline & $\begin{array}{l}\text { We have an obligation to } \\
\text { preserve urban nature for } \\
\text { future generations. }\end{array}$ & n.s. & n.s. & positive** $(\mathrm{r}=.35)$ & n.s. \\
\hline & $\begin{array}{l}\text { I would contribute } \\
\text { money to preserve urban } \\
\text { nature. }\end{array}$ & $\begin{array}{l}\text { positive** } \\
(\mathrm{r}=.29)\end{array}$ & n.s. & positive $^{* *}(\mathrm{r}=.34)$ & n.s. \\
\hline & $\begin{array}{l}\text { Urban animals and } \\
\text { plants have as much } \\
\text { right as humans to exist. }\end{array}$ & positive* $(\mathrm{r}=.2)$ & n.s. & positive $^{* *}(\mathrm{r}=.29)$ & n.s. \\
\hline
\end{tabular}

Note: * denotes significance level of $\mathrm{p}<.05, * *$ denotes significance level of $\mathrm{p}<.01$, n.s. denotes 'not significant'. Correlation with attitude factors was tested using Spearmann rho for IGS evaluation and point-biserial for IGS use (see Data analysis). 


\section{Discussion}

\subsection{Contributions to knowledge and survey limitations}

This study contributes new knowledge in two ways. First, previous research has mostly used small participant groups to gather qualitative data on one or a few different types of IGS (Campo, 2013; Rink \& Emmrich, 2005; Unt et al., 2013). Our study presents the first comprehensive, quantitative and qualitative examination of how residents interact with a wide variety of IGS types. Second, while previous research has focused mostly on Europe (Rink \& Herbst, 2011; Unt et al., 2013), the USA and Canada (Campo, 2013; Foster \& Sandberg, 2010; Platt, 2012), this study compares two culturally distinct settings from outside these regions. This provides insights into possible cultural influences on IGS use.

The comparatively low response rates (Brisbane 6.4\%, Sapporo 8.2\%) represent a limitation of our study, and thus care is necessary when analyzing and interpreting our results. Survey response rates have generally declined in recent years (Kohut, Keeter, Doherty, Dimock, \& Christian, 2012), and such low response rates are a known problem with postal surveys (Veal, 2011). Our results are similar to the response rate of $9.3 \%$ reported for a postal survey of national parks in South-East Queensland (Rossi, Pickering, \& Byrne, 2013). Resource constraints also prevented us from using techniques for improving response rates, such as financial incentives or follow-up post cards (Dillman, 1978).

Nonetheless, the survey provides a usable dataset for the exploratory research undertaken in this paper. Kohut and colleagues (2012) have demonstrated that for telephone surveys response rates below $10 \%$ did not necessarily influence the results, as the tendency to respond was not strongly related to a wide variety of respondents' views. The average age, educational level of attainment and income in our samples is similar to the general population census data, but less pronounced than results reported for a recent greenspace survey (Madureira, Nunes, Oliveira, Cormier, \& Madureira, 2015). As we mentioned earlier, we have used this comparison of respondents' demographic data with city-level census data to test for representativeness. Finally, the predominance of qualitative research on the topic of IGS use and perception makes comparison of our quantitative results challenging. 


\subsection{Perception, evaluation, and use of IGS}

Our results suggest that IGS is a prosaic part of everyday life and a feature of the urban landscape our respondents lived in. Most respondents knew of IGS in their neighborhood (Table 4). Most also reported that IGS influenced their daily life in a positive (Brisbane), or both in positive and negative ways (Sapporo, Figure 3). This finding contrasts with the depiction of IGS as spaces that only occur in urban 'interstices' (Jorgensen and Tylecote, 2007), or as anomalies rather than the norm. Vacant lots, road verges and river banks appear to be familiar elements of the urban landscape for our respondents (Table 4). Yet Unt and colleagues (2013) report that larger IGS sites such as brownfields, are often shown as blank or empty patches on city maps, which tend to strip these spaces of their diverse qualities (Qviström, 2012). Smaller spaces like verges or gaps tend to disappear altogether. This suggests that the liminal quality of IGS stems from their construction as marginal or transitory spaces in urban planning discourse. Yet respondents did not perceive IGS as merely empty space (Corbin, 2003), rather they perceived IGS to possess a quality that formal greenspace lacks:

"It's real, not fake like a park." (John, 41, male, from Brisbane)

"Unlike maintained greenspace, it has something you can grasp with all five senses, and I don't want it to disappear." (Midori, 35, female)

Fewer than $10 \%$ of respondents saw IGS as a 'waste of space', or believed that it should be developed (Table 5). This has implications for planning and management of urban greenspace, which we will return to later.

Surprisingly, a larger number of respondents than we expected (over 50\% in Brisbane, and $30 \%$ in Sapporo) reported they already used IGS for a variety of recreational activities (Figure 4). IGS use has been commonly reported (e.g., Campo, 2013; Unt et al., 2013), but the scarcity of quantitative data on IGS use in the literature has made it difficult to compare our findings. For example, Rall and Haase (2011) reported that $54 \%$ of respondents in a resident questionnaire were using brownfields that were already slightly modified (e.g., holes filled, paths installed) as part of an interim use program by the city of Leipzig, Germany. Given that our survey targeted spaces not managed for recreation, our results suggest IGS use could be more common than previously thought, but more research is needed to validate this finding. 
Our respondents' evaluation and use of IGS corroborates some findings from our literature review (e.g., benefits of IGS, preference for naturalness and cleanliness; Rupprecht \& Byrne, 2014b), but also provides new insights into the reasons why respondents use and value IGS. Respondents reported a wide variety of perceived potential benefits, including recreational, emotional and environmental benefits as well as ecosystem services (Table 5). For example, IGS users chose to use IGS rather than a park or garden because they felt it was less crowded and had no restrictions on use, in contrast to restrictions on formal greenspace (Figure 1). Similar to the findings of prior research on the challenges young people face in this regard (Ward Thompson, 2012), one respondent remarked:

"Today, there's no place for young teenagers to go, other than hanging out in front of convenience stores. Even in Doraemon (a famous Japanese cartoon, Authors' note) the children play in vacant lots every day. And parks are so over-maintained there's nothing except a few ants." (Akiko, 42, female, from Sapporo)

Respondents also chose to use IGS because it featured 'more or different animals or plants' (Table 6), suggesting that users value the sense of naturalness these places provide (Gobster $\&$ Westphal, 2004). This is evidenced by the fact that $40 \%$ of respondents believed that IGS is species rich. This finding suggests that IGS may not only provide residents with opportunities for nature contact, but could also play a role in conservation efforts in - and beyond - cities (Dunn et al., 2006). While these results indicate that respondents chose IGS to satisfy needs perhaps unmet by formal greenspace, the most common reason given for choosing IGS was proximity. This finding has also been reported by Platt (2012) in a study of children's recreation in Milwaukee (USA), but has otherwise not featured prominently in the IGS literature, even though researchers have shown that the frequency of residents' visits to formal greenspace is closely related to its proximity (e.g., Schipperijn et al., 2010).

Our findings regarding the common problems posed by IGS suggest a gap exists between perception and use of IGS. The potential problems of IGS that respondents perceived (e.g. littering, 'filthy and unorderly (sic) look'; Table 5) corroborate findings from prior research. For example, in a study of the Chicago River corridor, Gobster and Westphal (2004) found residents have a strong preference for cleanliness. Comments from respondents emphasize this point:

"A vacant lot full of weeds, with limited access and full of used needles wouldn't be a good thing." (Jessica, 32, female, from Brisbane) 
"Whilst I like nature, I also like things aesthetically pleasing. There is nothing pleasant, calming or relaxing in looking at/encountering a bit of a mess that looks neglected. The space could be used for growing veggies, community lots etc. It's the abandoned element I don't like." (Trudy, 55, female, from Brisbane)

Litter was the most common problem for respondents who used IGS for recreation (Table 6). Yet, in contrast to the $90 \%$ of respondents who reported litter as a problem, less than $20 \%$ of IGS users reported actually encountering litter. This gap between perception and experience may be related to socially constructed expectations of greenspace aesthetics (Nassauer, Wang \& Dayrell, 2009; Rink \& Emmrich, 2005). This can lead to sites with less active management being regarded as uncontrolled and unsafe spaces (Madge, 1997), rather than as ecologically valuable nature spaces (as is the case with Cranz and Bolund's 'sustainable parks') (Cranz \& Boland, 2004). It also has implications for managing IGS, which we discuss later.

\subsection{Factors influencing respondents' evaluation and use of IGS}

Three different factors appear to influence how respondents interacted with IGS besides geographic and cultural context: (i) respondent age, (ii) IGS use, and (iii) respondent attitude toward and self-reported knowledge of urban nature. The lack of quantitative studies on IGS again makes comparisons to the literature difficult. The positive correlation between respondent age and IGS use (Table 7) has been previously been reported for formal greenspace (Schipperijn et al., 2010), but has received little attention in the IGS literature. Our finding is that respondents who used IGS for recreation were likely to evaluate it more positively. This may be related to the gap between perceived IGS problems and problems encountered when using it. Because most IGS users reported no problems (Table 6), it seems likely that the benefits they derived from using IGS in turn contributed to their appreciation of IGS. This interaction is also noteworthy, as we did not originally consider it in our conceptual model (Figure 1). Respondents' attitude towards greenspace in their neighborhood, and towards urban nature in general, as well as their self-reported knowledge about local nature is correlated positively with IGS evaluation, and to a lesser degree with IGS use (Table 8). For the correlations between IGS use and attitude, the benefits IGS use offers may provide an explanation - respondents who value greenspace in their neighborhood and who possess knowledge about local nature could seek out IGS to satisfy their particular nature needs. 
On the other hand, to explain the connection between respondents' attitudes towards nature and IGS evaluation, we turn to respondents' qualitative comments. As discussed above, many respondents perceived IGS as species-rich and beneficial to animals and plants. However, in their comments, respondents also drew a connection between their emotional well-being and the presence of nature in the city in the form of IGS (including plants and animals):

"The changing colors of greenspace from season to season are pleasant to the eye and make you feel comforted. The air is delicious, and the wide space lets you feel relieved and satisfied. As a habitat and playground for wild animals, it gives a real feeling of living on this earth together.” (Kenji, 79, male)

"I'm using it for walks (including with my grandchildren), and it's scenery changing with the seasons, the plants and animals you meet - it fills me with joy.” (Yoko, 67, female)

"It makes suburbia seem less regimented. I feel better knowing that wildlife at least has a small sanctuary from over-development." (Aileen, 53, female)

While we cannot statistically establish a causational direction for the correlations, it seems plausible that respondents who assign intrinsic value to urban nature and/or see themselves as knowledgeable about local plants, animals or birds, may appreciate spaces that can provide habitat. Such respondents may feel that the benefits of IGS outweigh potential problems.

In our study the socio-demographic characteristics of respondent - sex, educational level of attainment and income - did not influence their evaluation or use of IGS. This contrasts with research on formal greenspace in Denmark that found differences in greenspace visits between men and women, and between respondents with longer or shorter education (Schipperijn, 2010). It also contrasts with research from the USA (Mowen, Payne, and Scott, 2005), which associated lower respondent income with perceptual constraints to formal greenspace access such as fear of crime, physically constrained access (either through lack of public transport, distance, or cost of transport), and with no interest in outdoor recreation.

The area of greenspace within $500 \mathrm{~m}$ of the respective sampling sites is not correlated with IGS use, evaluation, or number of IGS known in the neighborhood. A negative correlation between the area of formal greenspace within $500 \mathrm{~m}$ of our survey locations and respondents' use of IGS would have suggested it served as a substitute where formal greenspace was absent. A positive correlation could be interpreted as a result of respondents mistaking formal greenspace for IGS, or having become acculturated to using greenspace frequently due to its 
ample availability. However, because we found no such correlation, we suggest it may be more likely that respondents made a conscious choice to use IGS instead of formal greenspace. This would imply that IGS for them fulfilled a distinctive recreational role, an interpretation supported by the different reasons respondents provided for choosing IGS over formal greenspace (besides proximity) (Table 6).

\subsection{Differences between geographic and cultural contexts}

Our study reveals significant differences between respondents' perception, evaluation and use of IGS in Brisbane and Sapporo. However, differences between the two cities in factors influencing these interactions are limited. Brisbane respondents knew more IGS in their neighborhood, evaluated IGS' influence on their daily life more positively, and included more IGS users. One possible reason for these differences may be the different cultural context of the two cities. In a recent study on the dimensions of the human-nature relationship (Flint, Kunze, Muhar, Yoshida, \& Penker, 2013), researchers have suggested that differences exist in the way this relationship is interpreted. For example, in the Japanese literature these researchers reviewed, the human-nature dichotomy was less present. Rather, a reliance of humans on nature was shown to be connected with a long tradition of stewardship, but also respect for nature's destructive force. Such an image of the human-nature relationship could favor 'tended' nature over the intrinsic value of 'wild' nature, which is often linked with biodiversity. This difference in cultural context could also explain why Brisbane respondents had stronger ecocentric attitudes (Table 3). Moreover, their attitudes towards urban nature are correlated stronger with IGS evaluation than those of Sapporo respondents (Table 8). Another possible cultural difference could be how respondents spatially interpreted the term 'neighborhood'. Because Sapporo is more densely populated (Table 1), living in walking distance of amenities such as supermarkets or parks is likely more common than in Brisbane. As a result, the area that Sapporo respondents considered their neighborhood could be smaller, which in turn could mean it contained less IGS. Such cultural factors have implications for planning and management of IGS we will discuss in the next section.

Geographic context could also explain why respondents in Brisbane and Sapporo perceived, evaluated and used IGS differently. For example, residents in both cities have access to different amounts of greenspace (Table 1). In particular, how much IGS is present in respondents' vicinity, what types of IGS are present, the vegetation structure of local IGS, 
and its accessibility could be potential influence factors. In a survey of IGS quantity and characteristics in Brisbane and Sapporo (Rupprecht \& Byrne, 2014a), we showed that the amount of IGS in the surveyed area was not significantly different between both cities. However, IGS in Brisbane was dominated by street verges, while Sapporo had a wider diversity of IGS types - with vacant lots making up most of the IGS area. Sapporo IGS was more often covered by a herb vegetation layer, while Brisbane IGS had higher tree layer coverage. Fully accessible IGS was higher in Brisbane (78\%) than in Sapporo (68\%), but this could be compensated by a larger partially accessible IGS area in Sapporo (21\%) compared to Brisbane (7\%). All of these differences could play a role in influencing how respondents valued and used IGS in the two cities - a challenge to planning and management that we will now address.

\subsection{Implications for planning and management}

Our results corroborate the findings from our literature review (Rupprecht \& Byrne, 2014b) that IGS plays a role for recreation. Respondents did not perceive IGS as 'empty space' that should be developed. Planners may thus need to re-think their negative view of 'vacancy' in the urban landscape (Corbin, 2003). The goals and expectations for parks, as sole providers of greenspace benefits for those residents who lack gardens, might need to be reevaluated (Wolch, Byrne, \& Newell, 2014). For example, our study suggests that many cities could integrate IGS into their greenspace strategies, because the wide variety of IGS in cities already seems to be used and appears to play a different role from parks. However, since most IGS are not publicly owned and thus not simply 'available' for improved planning and design - many are legally (due to liability issues), historically, politically and financially constrained. Planners may be limited in their ability to directly influence IGS. Moreover, planners should retain a delicate balance between intervention and non-intervention.

Researchers have found that residents may resent the application of formal planning tools to IGS (Qviström, 2012) and both residents and IGS may be best served by a lack of 'hard management' from public administration (Hard, 2001). Campo (2013) has argued that replacing IGS with formal greenspace may not serve the original users, while Wolch and her colleagues (2014) have pointed out the danger of eco-gentrification associated with formalizing IGS. Yet, planners could work on identifying and reducing barriers to using these spaces (e.g. fencing off vacant lots; Hayashi, Tashiro, \& Kinoshita, 1999), and could provide nearby residents with information about the potential and availability of IGS (e.g. an IGS 
guide or map). Simply periodically reducing litter or making other small modifications (e.g., trimming vegetation along sight-lines; Rall \& Haase, 2011) may provide another way to improve residents' valuing of IGS and their perception of safety, as it would indicate that the place is cared for (Nassauer, 1988). Moreover, there may be opportunities for planners to work with community initiatives such as 596acres ("596 Acres: About Us," n.d.), a New York NGO that maps publicly owned vacant land and assists local residents in converting it to community gardens. The medium level of human influence needed to make IGS attractive might also be provided by users themselves, as a respondent to our survey suggested:

"Depending on the informal greenspace, it would be great to use it as a small playground or so. But because of litter problems it needs some management; we should make them into "talking spaces" people can have fun looking after and using them together, even use public funding for it!" (Akira, 71, male, from Sapporo)

Participative approaches to IGS management could provide alternative, cost-effective land management approaches. Residents involved could decide whether they prefer a more tended or 'wild' look, thus adapting management to the local cultural and geographic context. However, we still know little about how such approaches might succeed in the context of IGS - an important topic for further research.

\section{Conclusion}

In this study we have examined how residents perceived and used IGS in Brisbane, Australia and Sapporo, Japan. We used a mail-back questionnaire to collect data and analyzed factors that influenced respondents' interactions with IGS, as well as differences between the study cases. The study has broken new ground by combining qualitative and quantitative methods to compare residents' interaction with IGS across different continents and cultures, and has demonstrated that cross-cultural mixed method studies can provide rich and valuable insights. Limitations of our study include a comparatively low sample size and response rate of 123 valid responses (6.4\%) in Brisbane and 163 (8.2\%) in Sapporo, suggesting the need for follow-up studies with a larger sample size and better response rate, to verify whether the results of this exploratory study reflect perception and use of IGS in the general populations.

We found respondents in both cities knew, appreciated and used IGS in their neighborhood. They were attracted by its proximity, natural features and absence of use restrictions, but also valued a certain level of human influence. More than $30 \%$ of the respondents used IGS for 
recreational activities, irrespective of the amount of formal greenspace in their vicinity. This suggests that IGS plays an important role in recreation, different to that of traditional greenspace. While respondents differed in some aspects of IGS knowledge, evaluation and use, the functional role that IGS plays in respondents' lives was very similar in both cities we assessed. How respondents used and evaluated IGS was linked with their environmental disposition.

We propose several directions for future research. Both quantitative and qualitative methods should be applied further. The current lack of quantitative studies means we know little about the extent to which IGS is used, and it poses a challenge for drawing comparisons between quantitative and qualitative results. In-depth qualitative research, in the form of interviews, focus groups, participant observation, ethnography or participant photography could provide crucial information about what level and form of human influence residents consider is optimal, and what role they are able and willing to play in maintaining such levels. The potential for resident-led IGS management should be examined in greater detail by future research.

The role of IGS in relation to informality in urban planning also merits discussion, especially with regard to ambiguous semi-formal elements of the urban landscape (e.g. street verges, river banks). Moreover, cultural and geographic context as potential influence factors could prove vital in selecting appropriate management goals for IGS, a topic of particular importance in cities that are home to residents from diverse cultural backgrounds. Given that education and income were not significant influence factors in our study, further research could examine the potential of IGS as an alternative to eco-gentrification. Given the ethnoracial homogeneity of our sample, future research could investigate could investigate a possible influence of race and ethnicity on IGS use and perception, in multicultural cities such as Melbourne, Los Angeles, Amsterdam, Sao Paulo, London or Toronto. Finally, identifying ways of integrating the social and ecological heterogeneity of IGS into urban greenspace systems generally could directly and indirectly improve support for biodiversity conservation and bolster the ecological structure and function of urban greenspace systems in the future. 


\section{Acknowledgements}

This research was supported by the HDR research fund of the Griffith School of Environment, Griffith University, and by a grant by the Japan Society for the Promotion of Science (grant number 24658023). The authors are deeply grateful to Yumi Nakagawa for invaluable help with data collection, the Japanese survey instrument and data entry, to Kumiko Nakagawa for assistance with the Japanese survey instrument and Japanese qualitative responses, to Dr Jenni Garden, Prof Dr Jean-Marc Hero and Dr Bill Metcalf (Griffith University) for advice on research design, to the Brisbane and Sapporo councils for providing greenspace GIS datasets, and to all questionnaire respondents for participating in this study. This study was approved by Griffith University's human subjects research ethics committee (ENV/28/12/HREC).

\section{References}

596 Acres. (n.d.). 596 Acres: About Us. 596acres.org. Retrieved August 13, 2013, from http://www.596acres.org/en/about/about-596-acres/

Barron, P., \& Mariani, M. (Eds.). (2013). Terrain Vague. Abingdon: Routledge.

Byrne, J. (2012). When green is White: The cultural politics of race, nature and social exclusion in a Los Angeles urban national park. Geoforum, 43(3), 595-611. http://doi.org/10.1016/j.geoforum.2011.10.002

Byrne, J., \& Wolch, J. (2009). Nature, race, and parks: Past research and future directions for geographic research. Progress in Human Geography, 33(6), 743-765. doi:10.1177/0309132509103156

Byrne, J., Sipe, N., \& Searle, G. (2010). Green around the gills? The challenge of density for urban greenspace planning in SEQ. Australian Planner, 47(3), 162-177. doi:10.1080/07293682.2010.508204

Campo, D. (2013). The Accidental Playground. New York: Fordham University Press.

Corbin, C. I. (2003). Vacancy and the landscape: Cultural context and design response. Landscape Journal, 22(1), 12-24. doi:10.3368/1j.22.1.12

Cranz, G., \& Boland, M. (2004). Defining the Sustainable Park: A Fifth Model for Urban Parks. Landscape Journal, 23(2), 102-120.

Dillman, D. A. (1978). Mail and telephone surveys (Vol. 3). Wiley New York.

Drake, L., \& Lawson, L. J. (2014). Validating verdancy or vacancy? The relationship of community gardens and vacant lands in the U.S. Cities, 40, Part B, 133-142. http://doi.org/10.1016/j.cities.2013.04.007

Dunlap, R. E., Van Liere, K. D., Mertig, A. G., \& Jones, R. E. (2000). New trends in measuring environmental attitudes: Measuring endorsement of the New Ecological Paradigm: a revised NEP Scale. Journal of Social Issues, 56(3), 425-442. doi:10.1111/0022-4537.00176

Dunn, R. R., Gavin, M. C., Sanchez, M. C., \& Solomon, J. N. (2006). The Pigeon Paradox: Dependence of Global Conservation on Urban Nature. Conservation Biology, 20(6), 1814-1816. http://doi.org/10.1111/j.1523-1739.2006.00533.x

Field, A. (2009). Discovering statistics using SPSS. London: SAGE.

Flint, C. G., Kunze, I., Muhar, A., Yoshida, Y., \& Penker, M. (2013). Exploring empirical typologies of human-nature relationships and linkages to the ecosystem services concept. Landscape and Urban Planning, 120, 208-217. doi:10.1016/j.landurbplan.2013.09.002

Foo, K., Martin, D., Wool, C., \& Polsky, C. (2013). The production of urban vacant land: 
Relational placemaking in Boston, MA neighborhoods. Cities, 35, 156-163. doi:10.1016/j.cities.2013.06.012

Foster, J. (2014). Hiding in plain view: Vacancy and prospect in Paris' Petite Ceinture. Cities, 40, Part B, 124-132. http://doi.org/10.1016/j.cities.2013.09.002

Foster, J., \& Sandberg, L. A. (2010). Friends or Foe? Invasive Species and Public Green Space in Toronto. Geographical Review, 94(2), 178-198. doi:10.1111/j.19310846.2004.tb00166.x

Franck, K. A., \& Stevens, Q. (Eds.). (2007). Loose space: Possibility and diversity in urban life. Abingdon: Routledge.

Gobster, P., \& Westphal, L. (2004). The human dimensions of urban greenways: Planning for recreation and related experiences. Landscape and Urban Planning, 68, 147-165. doi:10.1016/S0169-2046(03)00162-2

Haase, D. (2008). Urban ecology of shrinking cities: An unrecognized opportunity? Nature and Culture, 3(1), 1-8. doi:10.3167/nc.2008.030101

Hard, G. (2001). Natur in der Stadt? (Nature in the city?) Berichte Zur Deutschen Landeskunde, 75(2/3), 257-270.

Hayashi, M., Tashiro, Y., \& Kinoshita, T. (1999). A study on vacant lots enclosed by fences in relation to urbanization. Journal of the Japanese Institute of Landscape Architecture, 63(5), 667-670. doi:10.5632/jila.63.667

Jonas, M. C. (2007). Private use of public open space in Tokyo A study of the hybrid landscape of Tokyo's informal gardens. Journal of Landscape Architecture, 2(2), 18 29.

Jorgensen, A., \& Keenan, R. (Eds.). (2012). Urban Wildscapes. Abingdon: Routledge.

Jorgensen, A., \& Tylecote, M. (2007). Ambivalent landscapes-wilderness in the urban interstices. Landscape Research, 32(4), 443-462. http://doi.org/10.1080/01426390701449802

Kohut, A., Keeter, S., Doherty, C., Dimock, M., \& Christian, L. (2012). Assessing the representativeness of public opinion surveys. Pew Research Center, Washington, DC.

Kremer, P., Hamstead, Z. A., \& McPhearson, T. (2013). A social-ecological assessment of vacant lots in New York City. Landscape and Urban Planning, 120(0), 218-233. doi:10.1016/j.landurbplan.2013.05.003

La Trobe, H. L., \& Acott, T. G. (2000). A Modified NEP/DSP environmental attitudes scale. The Journal of Environmental Education, 32(1), 12-20. doi:10.1080/00958960009598667

Langegger, S. (2013). Emergent public space: Sustaining Chicano culture in North Denver. Cities, 35, 26-32. http://doi.org/10.1016/j.cities.2013.04.013

Maat, K., \& de Vries, P. (2006). The influence of the residential environment on green-space travel: Testing the compensation hypothesis. Environment and Planning A, 38, 21112127.

Madge, C. (1997). Public parks and the geography of fear. Tijdschrift Voor Economische en Sociale Geografie, 88(3), 237-250. doi:10.1111/j.1467-9663.1997.tb01601.x

Madureira, H., Nunes, F., Oliveira, J. V., Cormier, L., \& Madureira, T. (2015). Urban residents' beliefs concerning green space benefits in four cities in France and Portugal. Urban Forestry \& Urban Greening, 14(1), 56-64. http://doi.org/10.1016/j.ufug.2014.11.008

Matsuoka, R. H., \& Kaplan, R. (2008). People needs in the urban landscape: Analysis of Landscape And Urban Planning contributions. Landscape and Urban Planning, 84(1), 7-19. doi:10.1016/j.landurbplan.2007.09.009

Mowen, A. J., Payne, L. L., \& Scott, D. (2005). Change and Stability in Park Visitation Constraints Revisited. Leisure Sciences, 27(2), 191-204. 
http://doi.org/10.1080/01490400590912088

Nassauer, J. I. (1988). The Aesthetics of Horticulture: Neatness as a Form of Care. HortScience, 23(6), 973-977.

Nassauer, J. I., Wang, Z., \& Dayrell, E. (2009). What will the neighbors think? Cultural norms and ecological design. Landscape and Urban Planning, 92(3-4), 282-292. http://doi.org/10.1016/j.landurbplan.2009.05.010

Nordh, H., \& Østby, K. (2013). Pocket parks for people-A study of park design and use. Urban Forestry \& Urban Greening, 12(1), 12-17. doi:10.1016/j.ufug.2012.11.003

Næss, P. (2005). Residential location affects travel behavior-but how and why? The case of Copenhagen metropolitan area. Progress in Planning, 63(2), 167-257. doi:10.1016/j.progress.2004.07.004

Özgüner, H., \& Kendle, A. (2006). Public attitudes towards naturalistic versus designed landscapes in the city of Sheffield (UK). Landscape and Urban Planning, 74(2), 139157. doi:10.1016/j.landurbplan.2004.10.003

Peschardt, K. K., Schipperijn, J., \& Stigsdotter, U. K. (2012). Use of Small Public Urban Green Spaces (SPUGS). Urban Forestry \& Urban Greening, 11(3), 235-244. doi:10.1016/j.ufug.2012.04.002

Platt, L. (2012). "Parks are dangerous and the sidewalk is closer": Children's use of neighborhood space in Milwaukee, Wisconsin. Children Youth and Environments, 22(2), 194-213.

Qiu, L., Lindberg, S., \& Nielsen, A. B. (2013). Is biodiversity attractive?-On-site perception of recreational and biodiversity values in urban green space. Landscape and Urban Planning, 119, 136-146. doi:10.1016/j.landurbplan.2013.07.007

Queensland Government, Department of National Parks Recreation Sport and Racing. (2012). QPWS monitors fire near Brisbane's D'Aguilar National Park. Department of National Parks, Recreation, Sport and Racing. Retrieved 2012, from http://www.nprsr.qld.gov.au/mediareleases/2012-12-qpws-monitors-fire.html

Qviström, M. (2012). Taming the wild: Gyllin's Garden and the urbanization of a wildscape. In A. Jorgensen \& R. Keenan (Eds.), Urban Wildscapes (pp. 187-200). Abingdon: Routledge.

Rall, E. L., \& Haase, D. (2011). Creative intervention in a dynamic city: A sustainability assessment of an interim use strategy for brownfields in Leipzig, Germany. Landscape and Urban Planning, 100(3), 189-201. doi:10.1016/j.landurbplan.2010.12.004

Rink, D., \& Emmrich, R. (2005). Surrogate nature or wilderness? Social perceptions and notions of nature in an urban context. In I. Kowarik \& S. Körner (Eds.), Wild Urban Woodlands (pp. 67-80). Berlin/Heidelberg: Springer. doi:10.1007/3-540-26859-6_4

Rink, D., \& Herbst, H. (2011). From wasteland to wilderness - aspects of a new form of urban nature. In M. Richter \& U. Weiland (Eds.), Applied Urban Ecology: A Global Framework (pp. 82-92). Chichester, UK: Wiley-Blackwell. doi:10.1002/9781444345025.ch7

Rossi, S. D., Pickering, C. M., \& Byrne, J. (2013). Attitudes of local communities: Assessing the social impacts of the South East Queensland Horse Riding Trail Network. Department of Science, Information Technology, Innovation and the Arts, Brisbane.

Rupprecht, C. D. D., Byrne, J. A., \& Lo, A. Y. H. (2015). Memories of vacant lots: How and why residents used informal urban greenspace as children and teenagers in Brisbane, Australia and Sapporo, Japan. Children's Geographies. http://doi.org/10.1080/14733285.2015.1048427

Rupprecht, C. D. D., \& Byrne, J. (2014a). Informal urban green-space: comparison of quantity and characteristics in Brisbane, Australia and Sapporo, Japan. PLoS ONE, 9(6), e99784. http://doi.org/10.1371/journal.pone.0099784 
Rupprecht, C. D. D., \& Byrne, J. A. (2014b). Informal urban greenspace: a typology and trilingual systematic review of its role for urban residents and trends in the literature. Urban Forestry \& Urban Greening, 13(4), 597-611. http://doi.org/10.1016/j.ufug.2014.09.002

Sapporo Kankyōkyoku Midori No Suishinbu. (2013). Bear sighting information. City of Sapporo. Retrieved October 20, 2013, from http://www.city.sapporo.jp/kurashi/animal/choju/kuma/syutsubotsu/index.html

Schipperijn, J., Ekholm, O., Stigsdotter, U. K., Toftager, M., Bentsen, P., Kamper-Jørgensen, F., \& Randrup, T. B. (2010). Factors influencing the use of green space: Results from a Danish national representative survey. Landscape and Urban Planning, 95(3), 130137. http://doi.org/10.1016/j.landurbplan.2009.12.010

Schneekloth, L. (2007). Unruly and robust: An abandoned industrial river. In K. A. Franck \& Q. Stevens (Eds.), Loose space: Possibility and diversity in urban life (pp. 253-270). Routledge.

Sproule, W. (2006). Content analysis. In M. Walter (Ed.), Social research methods: An Australian perspective (pp. 114-133). Oxford: Oxford University Press.

Unt, A.-L., Travlou, P., \& Bell, S. (2013). Blank space: exploring the sublime qualities of urban wilderness at the former fishing harbour in Tallinn, Estonia. Landscape Research, 39(3), 267-286.

Ueda, H., \& Rupprecht, C. D. D. (2014). The Role of Green Spaces in the City Image of Sapporo. Journal of The Japanese Institute of Landscape Architecture, 77(5), 487-490.

Veal, A. J. (2011). Research Methods for Leisure \& Tourism. Harlow: Financial Times Prentice Hall.

Ward Thompson, C. (2012). Places to be wild in nature. In A. Jorgensen \& R. Keenan (Eds.), Urban Wildscapes (pp. 49-63). Abingdon: Routledge.

Wolch, J. R., Byrne, J., \& Newell, J. P. (2014). Urban green space, public health, and environmental justice: The challenge of making cities "just green enough." Landscape and Urban Planning, 125, 234-244. 
Supplementary Material 1 - Questionnaire IGS typology

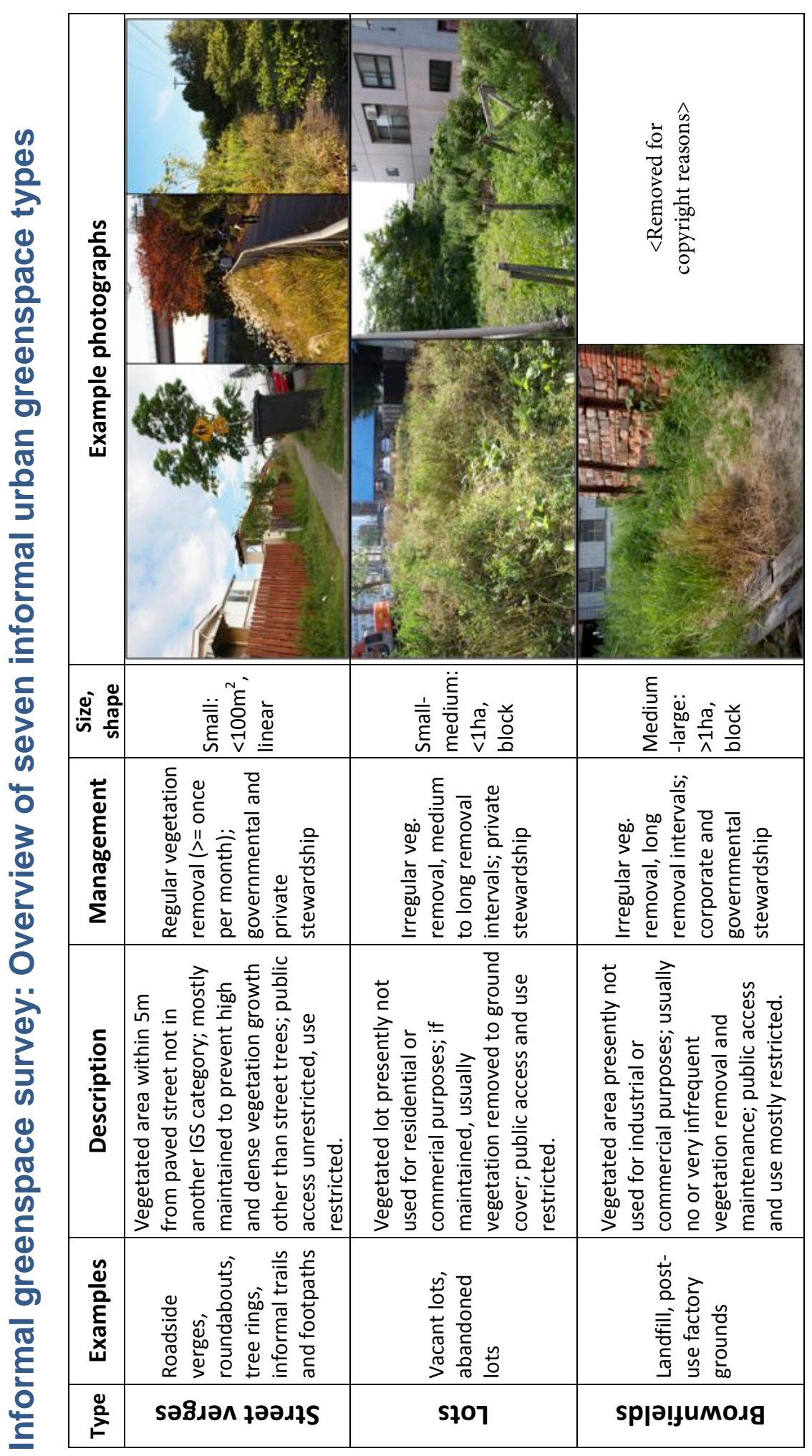

$\frac{N}{0}$ 


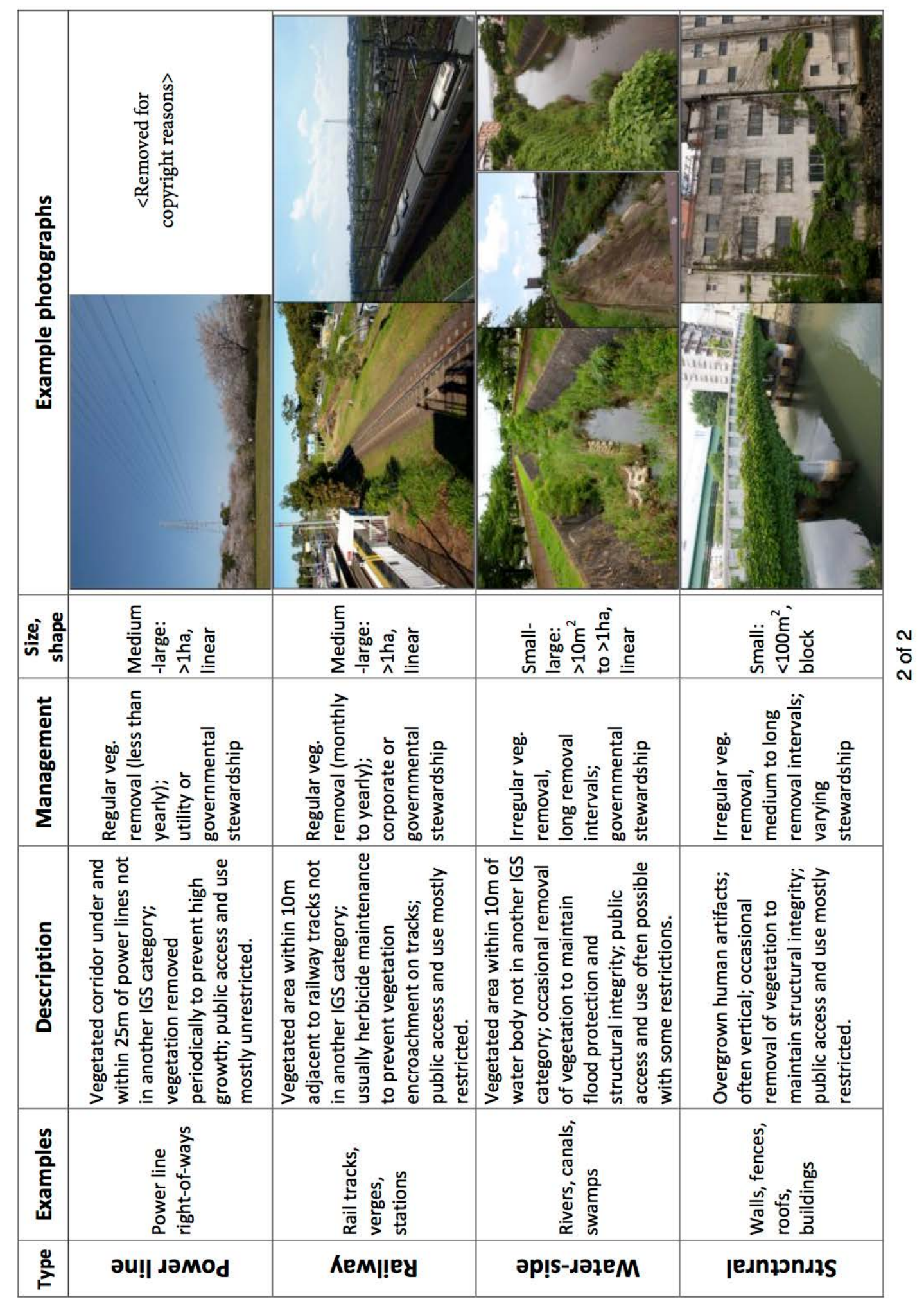

